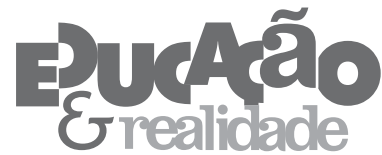 \\ Currículo e Ensino de História: um estado do conhecimento no Brasil
}

\author{
Francisco Thiago Silva' \\ Lívia Freitas Fonseca Borges' \\ 'Universidade de Brasília (UnB), Brasília/DF - Brasil
}

RESUMO - Currículo e Ensino de História: um estado do conhecimento no Brasil. O presente artigo tem como pressuposto: a busca por uma formação crítica nos cursos de Pedagogia do Brasil pode materializar um conhecimento poderoso (Young, 2007) se o currículo prescrito (Sacristán, 2000) contemplar o ensino de História com a mesma densidade atribuída às outras disciplinas. Optou-se pela metodologia de análise documental para constituir o estado do conhecimento, tomando a avaliação de textos publicados pela Associação Nacional de Pesquisadores em Educação, no Encontro Nacional de Didática e Práticas de Ensino e a exploração de textos cadastrados na Rede SciELO. As categorias escolhidas: pedagogia, currículo, integração/ interdisciplinaridade e ensino de História dialogam com a questão central e com a suposição de pesquisa.

Palavras-chave: Currículo. Ensino de História. Brasil.

ABSTRACT - Curriculum and History Teaching: a state of the knowledge in Brazil. The premise of this article is the search for a critical training in Brazilian Pedagogy courses can materialize a powerful knowledge (Young, 2007) if the prescribed curriculum (Sacristán, 2000) assigns to History teaching the same density as to other disciplines. It was developed a documental analysis to establish the state of the knowledge, through the exam of texts published by the National Association of Researchers in Education, at the National Meeting of Didactics and Teaching Practices and exploration of texts found in SciELO network. The categories chosen - pedagogy, curriculum, integration/interdisciplinarity and History teaching - establish a dialogue with the central issue and with the research question. Keywords: Curriculum. History Teaching. Brazil.

Educação \& Realidade, Porto Alegre, v. 43, n. 4, p. 1693-1723, out./dez. 2018.1693 http://dx.doi.org/10.1590/2175-623676735 


\section{Mapeando o Caminhar: primeiras palavras}

Define-se a partir de Ferreira (2002) estado do conhecimento ou estado da arte como uma rede de trabalhos e pesquisas ligados por categorias e sínteses do conhecimento que ganham significado quando são inventariados, ordenados, classificados e relacionados com o objeto que se esteja pesquisando. Nesse caso, pretendeu-se alimentar a teoria que será confrontada com a análise empírica, aqui iniciada, na busca por essa caracterização parcial do mundo concreto. Trata-se do próprio domínio empírico da teoria.

O objetivo central deste artigo é delinear um estado do conhecimento que apresentasse as reflexões relativas aos textos completos publicados ${ }^{1}$ nos eventos científicos e revistas da Associação Nacional de Pesquisadores em Educação (Anped), desde sua criação, além do Encontro Nacional de Didática e Práticas de Ensino (Endipe) (resumos) e dos textos acadêmicos completos divulgados na Rede SciELO.

A Anped tem por demanda discutir, por meio dos seus vinte e quatro grupos de trabalho, os principais temas que cercam o campo educacional no país. Todavia, o Endipe reúne intelectuais em volta da área de Didática e prática de ensino. Como o campo curricular está intrinsecamente ligado à própria Organização do Trabalho Pedagógico (Freitas, 1995), almeja-se investigar qual o espaço e as principais abordagens que o evento em tela tem dado ao tema. O portal Scielo agrupa os textos acadêmicos mais expressivos do Brasil e de outros países, consequentemente traz pesquisas consolidadas, geralmente de estudiosos importantes e consagrados nas instituições e nos eventos de pesquisa.

Trilhado o caminho a percorrer, pretende-se verificar de que forma as categorias centrais que fomentam a pesquisa (Pedagogia, currículo integrado, interdisciplinaridade e ensino de História) estão sendo discutidas nesses espaços científicos. A opção por esse universo de pesquisa justifica-se, novamente, porque a Rede SciELO traz os textos científicos mais bem avaliados do país, já os dois outros eventos, a Anped e o Endipe, além do grau de representatividade que expressam, concentram os pesquisadores de maior expressão do campo educacional. É relevante destacar que as categorias anteriormente delineadas só fazem sentido quando se problematiza suas fontes, autores e a relação entre as mesmas.

Uma pesquisa dessa natureza, embora seja estritamente teórica, tem muito valor ao trazer algumas pistas sobre como cada categoria foi pensada ao longo do tempo. Ao ventilar os debates das respectivas temáticas, é possível demonstrar em quais sentidos elas avançaram e quais elementos ainda podem ser explorados. O esforço destes autores caminha nessa direção.

\section{Os Trabalhos Publicados na Anped}

A Anped, fundada em março de 1978, tem compromisso com a qualidade da educação e ampliação dos direitos relativos a essa seara, 
tem ainda, notável participação nos processos de discussão e renovação acerca dos grandes temas das pesquisas na área de educação no país. Por essa razão, compreende-se que é relevante conhecer como os eixos de pesquisa foram discutidos ao longo das 37 (trinta e sete) reuniões nacionais, detendo-se o olhar no GT 12 (Grupo de Trabalho) de Currículo. A associação reúne pesquisadores e instituições de todas as regiões do Brasil e conta, além de sua reunião nacional, com encontros regionais que visam fortalecer as práticas de pesquisa no maior número possível de estados e municípios, conforme informações da própria instituição:

\begin{abstract}
A Anped é uma entidade sem fins lucrativos que congrega programas de pós-graduação stricto sensu em educação, professores e estudantes vinculados a estes programas e demais pesquisadores da área. Ela tem por finalidade o desenvolvimento da ciência, da educação e da cultura, dentro dos princípios da participação democrática, da liberdade e da justiça social. Dentre seus objetivos destacam-se: fortalecer e promover o desenvolvimento do ensino de pós-graduação e da pesquisa em educação (ANPED, online).
\end{abstract}

Serão apresentados, não obstante, apenas os textos a partir da $23^{a}$ Reunião do ano 2000, totalizando 15 (quinze) eventos científicos, uma vez que as anteriores não se encontram disponíveis para consulta ${ }^{2}$. Buscou-se captar nas pesquisas alguma relação com o objeto no que se refere aos grandes eixos de pesquisa: Pedagogia, currículo integrado, interdisciplinaridade e ensino de História na formação inicial do pedagogo.

Para um melhor entendimento, organizou-se uma tabela com os principais textos coletados. Ao todo são 17 (dezessete) que em seguida serão discutidos conforme ordenação abaixo e na íntegra (Tabela 1).

Tabela 1 - Distribuição Temporal dos Trabalhos ${ }^{3}$ Catalogados por Ano de Publicação - Anped (continua)

\begin{tabular}{|c|c|c|c|}
\hline Ano & Local & Título & Autor/es \\
\hline 2000 & $\underset{\text { MG }}{\text { Caxambu }}$ & Não foram captados trabalhos. & \\
\hline 2001 & $\underset{\mathrm{MG}}{\text { Caxambu }}$ & $\begin{array}{l}\text { 1. Quando o Currículo faz a diferença ... O Currí- } \\
\text { culo Integrado na formação em serviço do técnico } \\
\text { em Higiene Dental. } \\
\text { 2. A concepção de currículo integrado e o ensino } \\
\text { de química no “novo ensino médio". } \\
\text { 3. Competências - um conceito recontextualizado } \\
\text { no currículo para a formação de professores no } \\
\text { Brasil. }\end{array}$ & $\begin{array}{l}\text { 1.Eliana Maria } \\
\text { de Oliveira Sá } \\
\text { (ESMIG/CF) / Rita } \\
\text { Amélia Teixeira } \\
\text { Vilela } \\
\text { 2.Rozana Gomes } \\
\text { de Abreu (UFRJ) } \\
\text { 3. Rosanne Evange- } \\
\text { lista Dias (UFRJ) }\end{array}$ \\
\hline 2002 & $\underset{\text { MG }}{\text { Caxambu }}$ & $\begin{array}{l}\text { 1. Construindo interpretações sobre integração } \\
\text { disciplinar: análises de uma experiência de ino- } \\
\text { vação curricular a partir de produções de alunos } \\
\text { e professores. }\end{array}$ & $\begin{array}{l}\text { 1.André Pietsch } \\
\text { Lima (UNICAMP) }\end{array}$ \\
\hline
\end{tabular}

Educação \& Realidade, Porto Alegre, v. 43, n. 4, p. 1693-1723, out./dez. 2018.1695 
Currículo e Ensino de História

\begin{tabular}{|c|c|c|c|}
\hline Ano & Local & Título & Autor/es \\
\hline 2003 & $\begin{array}{c}\text { Poços de } \\
\text { Caldas } \\
\text { MG }\end{array}$ & Não foram captados trabalhos. & ----- \\
\hline 2004 & $\underset{\text { MG }}{\text { Caxambu }}$ & Não foram captados trabalhos. & ----- \\
\hline 2005 & $\underset{\text { MG }}{\text { Caxambu }}$ & $\begin{array}{l}\text { 1. A disciplina escolar história: reinterpretações } \\
\text { curriculares no contexto da prática. }\end{array}$ & $\begin{array}{l}\text { 1. Ana de Oliveira } \\
\text { - UERJ }\end{array}$ \\
\hline 2006 & $\underset{\text { MG }}{\text { Caxambu }}$ & $\begin{array}{l}\text { 1. História, Currículo e Práticas Pedagógicas: } \\
\text { sobre memórias e narrativas. }\end{array}$ & $\begin{array}{l}\text { 1.Maria do Carmo } \\
\text { Martins }\end{array}$ \\
\hline 2007 & $\underset{\mathrm{MG}}{\text { Caxambu }}$ & $\begin{array}{l}\text { * Sessão Especial: Cooperação Interdisciplinar e } \\
\text { Produção do Conhecimento em Educação:ressig- } \\
\text { nificações semânticas no campo das disciplinas } \\
\text { 1. Da interdisciplinaridade hipotética de um } \\
\text { currículo a um currículo interdisciplinarmente } \\
\text { materializado. } \\
\text { 2. Currículo, ensino de história e narrativa. }\end{array}$ & $\begin{array}{l}\text { *Alfredo Veiga- } \\
\text {-Neto - ULBRA / } \\
\text { UFRGS } \\
\text { 1. César Augusto } \\
\text { Castro } \\
\text { 2. Carmen Teresa } \\
\text { Gabriel Anhorn / } \\
\text { Ana Maria Ferreira } \\
\text { da Costa Monteiro }\end{array}$ \\
\hline 2008 & $\begin{array}{c}\text { Caxambu } \\
\text { MG }\end{array}$ & Não foram captados trabalhos. & \\
\hline 2009 & $\underset{\text { MG }}{\text { Caxambu }}$ & $\begin{array}{l}\text { 1. O processo de significação da política de inte- } \\
\text { gração curricular em Niterói, RJ. } \\
\text { 2. Ensino profissionalintegrado:projetos de traba- } \\
\text { lho sob a ótica da transdisciplinaridade. } \\
\text { 3. Currículo e ensino de história: desencaixes e } \\
\text { reencaixes em um mundo de globalizações. }\end{array}$ & $\begin{array}{l}\text { 1. Danielle dos } \\
\text { Santos Matheus } \\
\text { 2. Everardo de } \\
\text { Souza Luz } \\
\text { 3.Fernando César } \\
\text { Sossai/ } \\
\text { Geovana Men- } \\
\text { donça Lunardi }\end{array}$ \\
\hline 2010 & $\underset{\text { MG }}{\text { Caxambu }}$ & Não foram captados trabalhos. & \\
\hline 2011 & Natal RN & $\begin{array}{l}\text { 1. A integração curricular na Educação em Tem- } \\
\text { po Integral: Perspectivas de uma parceria inte- } \\
\text { rinstitucional. } \\
\text { 2. Pesquisas e propostas curriculares para o en- } \\
\text { sino de história: a diversidade como hegemonia. }\end{array}$ & $\begin{array}{l}\text { 1.Helena Maria } \\
\text { dos Santos Ferreira } \\
\text { Felício } \\
\text { 2. Olavo Pereira } \\
\text { Soares }\end{array}$ \\
\hline 2012 & $\begin{array}{l}\text { Porto de } \\
\text { Galinhas } \\
\text { PE }\end{array}$ & $\begin{array}{l}\text { 1. Articulações discursivas sobre conhecimento } \\
\text { no currículo de pedagogia. }\end{array}$ & $\begin{array}{l}\text { 1. Márcia Cristina } \\
\text { de Souza Pugas/ } \\
\text { Ana Paula Batalha } \\
\text { Ramos }\end{array}$ \\
\hline 2013 & $\begin{array}{l}\text { Goiânia } \\
\text { GO }\end{array}$ & Não foram captados trabalhos & ----------------- \\
\hline 2015 & $\begin{array}{l}\text { Florianó- } \\
\text { polis } \\
\text { SC }\end{array}$ & $\begin{array}{l}\text { 1. O campo pedagógico como antagonismo nas } \\
\text { políticas curriculares para o ensino da História. } \\
\text { 2. Tessitura de uma alternativa curricular a partir } \\
\text { das vivências cotidianas: o ensino de história e } \\
\text { a sala de aula como espaço tempo de pesquisa. }\end{array}$ & $\begin{array}{l}\text { 1. Ana de Oliveira } \\
\text { 2. Joana Ribeiro } \\
\text { dos Santos }\end{array}$ \\
\hline
\end{tabular}

Fonte: Elaborada pelos autores.

Discutir-se-á o ponto central de avanços e controvérsias de cada produção elencada nas três fontes de pesquisa, e ao final de cada seção serão indicados os caminhos possíveis para ampliação do leque de discussões. Ao término do texto, esse movimento se dará de forma mais interligada.

1696 Educação \& Realidade, Porto Alegre, v. 43, n. 4, p. 1693-1723, out./dez. 2018. 
Sá e Vilela (2001) apontam que o modelo de currículo integrado em Bernstein, adotado na qualificação profissional de cursos técnicos em higiene dental observados, se aproxima da concepção proposta pelo inglês, já que a prática curricular revelou-se inovadora e libertadora, pois não excluíram os códigos restritos presentes no curso, ao contrário, ressignificou-os e formou seus agentes numa base emancipadora com condições de ampliarem este código por meio da integração das múltiplas atividades práticas que a formação ofereceu.

O texto de Abreu (2001) alerta que a proposta integradora para o currículo de Química, presente nos Parâmetros Curriculares Nacionais do Ensino Médio (PCNEM) tende a se diluir em apenas mais uma proposta teórica, posto que a integração em questão se identifica apenas com o conhecimento científico e com a supervalorização das tecnologias. A autora adverte que: somadas a forte divisão disciplinar na etapa e o esvaziamento teórico do conceito, o que permanece são proposições no máximo pluridisciplinares como caminho para a integração, mas em nível tecnicamente metodológico e não como conceito problematizado de forma ampla teoricamente.

Dias (2001) problematiza o novo paradigma das competências e da relação dos documentos oficiais que sustentavam a formação de professores no Brasil no início da década de 2000. Com base em Bernstein, a autora conclui que: o currículo da formação inicial com tal característica se aproxima da ideia praticada na educação profissional que tende a formar o profissional prático; os professores seriam os únicos responsáveis pela sua formação continuada; a proposta pode resultar num esvaziamento do espaço do conteúdo teórico em detrimento do saber técnico/prático; há uma gestão empresarial que pretende por meio da proposta da integração aproximar processos de formação e escolarização com o sistema econômico produtivo e ainda realinhar o caráter tecnicista e conteudista do currículo.

A partir das teorias pós-críticas de currículo, Lima (2002) tentou desvelar como a integração disciplinar no currículo do curso de formação inicial de professores de Ciências e Biologia da UNESP (1996-2000) produziu diferentes identidades. O autor é enfático ao defender a necessidade de desterritorialização e o entendimento do cotidiano para a superação da integração mecânica entre áreas. O autor faz uso da ideia de eixo estruturante, mas não o define teoricamente.

O currículo dos anos finais da disciplina História é analisado por Oliveira (2005). A partir da Lei de Diretrizes e Bases (LDB) (Brasil, 1996) e dos Parâmetros Curriculares Nacionais (PCN'S), a autora sinaliza que a escola deve ser espaço de reinterpretação dos discursos engendrados fora dela. A instituição de ensino escolar consegue produzir novos significados na prática curricular a partir da prescrição dada. Por exemplo, o caso dos professores do Colégio Pedro II (espaço da pesquisa) que ressignificaram as práticas do ensino de História por meio da adesão de eixos temáticos para vencer a memorização e linearidade que marcavam a área de caráter estritamente disciplinar.

Educação \& Realidade, Porto Alegre, v. 43, n. 4, p. 1693-1723, out./dez. 2018.1697 
Buscando compreender a fluidez e a permanência de práticas curriculares das experiências de seus estudantes de Pedagogia da UNICAMP, Martins (2006) faz uso do memorial para captar como o currículo pode ser refletido nos relatos e reconfigurado a partir do debate com os textos referenciais do campo no processo de formação do pedagogo. A pesquisadora alerta, entretanto, que pesquisar a própria prática e experiência, caso não sejam observados todos os rigores teóricos e metodológicos, pode resultar numa investigação imprecisa e tendenciosa.

Em Sessão Especial realizada em 2007, Veiga-Neto analisa como as disciplinas e seus eixos de saberes - como o autor denomina - têm ganhado diferentes significados e formas de representação no espaço educacional com base em Foucault. O estudioso admite que as áreas do conhecimento só farão sentido na medida em que se puder enxergar que elas representem um estado de coisas, uma ação de uma situação provisória. Assim, torna-se mais tácito entender como a produção e a circulação dos conhecimentos disciplinares se configuram no processo de apropriação dos currículos escolares.

O texto de Castro (2007) defendeu a necessidade de a educação adotar uma postura interdisciplinar com relação à materialização de seus currículos. Para o autor, é no fortalecimento das disciplinas que este currículo real e concreto se efetivará para além dos slogans (Santomé, 1998), e como mecanismo central na organização do trabalho pedagógico.

Assumindo a condição pós-moderna sob um olhar pós-crítico e pós-estruturalista de currículo, Anhorn e Monteiro (2007) pretenderam ir além da crítica que se faz às metanarrativas e recorreram à narrativa histórica como elemento central para a reconceituação do campo teórico do currículo do ensino de História. Para as autoras, é o estreitamento discursivo dos campos da epistemologia, História e currículo que produzirá referenciais teórico-metodológicos capazes de subsidiar a leitura dos sujeitos implicados na modelagem curricular (Sacristán, 2000), na compreensão e explicação da produção dos conteúdos históricos ensinados nas escolas.

A partir da teoria pós-crítica e com a sustentação teórica de autores brasileiros, Matheus (2009) analisa a reforma curricular da rede municipal de Niterói, RJ no triênio que vai de 2005 a 2008, no que diz respeito à suposta proposta de integração curricular, confrontando os documentos curriculares do município com a fala (discurso) dos professores da rede pública municipal de ensino. A autora assume que políticas de currículos são políticas culturais expressas em textos e discursos e modeladas (Sacristán, 2000) pela própria escola em seu cotidiano. Conclui que no contexto da prática, apesar das fragilidades documentais, o município ainda busca a interdisciplinaridade para superar as divisões clássicas entre as disciplinas.

Luz (2009) analisa a materialização de projetos classificados como integradores no componente curricular Física, realizados no Colégio Agrícola de Floriano, Piauí. A prática pedagógica demonstra muita dinâmica e interatividade entre estudantes e professores mesmo tendo 
ocorrido na conturbada relação entre ensino médio e ensino profissional. Por fim, o autor constata que o estudo teórico alimenta experiências de sucesso, como as analisadas por ele, de caráter transdisciplinar.

O texto de Sossai e Lunardi (2009) analisa a série televisiva Brasil 500 anos para denunciar o uso indistinto de kits tecnológicos como sendo o antídoto para os problemas da educação. Segundo os autores, muitas vezes utilizar programas e tecnologias na educação, de maneira acrítica, nada mais é do que garantir que esses veículos de globalização esfacelem o currículo, no caso analisado, de História, quando docentes utilizam apenas determinados recursos.

Felício (2011) analisa a integração curricular realizada por uma parceria interinstitucional entre uma escola pública e uma organização sem fins lucrativos de uma cidade no interior de São Paulo. O texto pressupõe que toda integração curricular se sustenta em quatro dimensões: integração das experiências, integração do conhecimento, integração social e integração como concepção curricular. Isso ocorreu quando os espaços formativos analisados trabalharam junto à comunidade para praticar um currículo em tempo integral e integrado sem o caráter de apenas estabelecer relação pedagógica de complementaridade entre as partes, mas garantir práticas que superem o cotidiano e formem seres humanos emancipados, capazes de interpretar e modificar, quando for preciso, sua realidade.

A pesquisa de Soares (2011), com base em estudos documentais de algumas secretarias estaduais e municipais de educação, denuncia que há um processo de silenciamento em torno do materialismo histórico dialético e de suas possibilidades de inserção nos debates sobre o ensino de História. O agravamento da situação leva à percepção de que as produções teóricas do campo do ensino da disciplina e os documentos curriculares apresentam a história marxista de forma quase pejorativa, pois a vincula à história metódica e até à história positivista. Para Soares (2011), o resultado do processo de apagamento da história marxista traz para o centro do currículo uma História imediata, miúda e do cotidiano.

Pugas e Ramos (2012) investigam qual o conhecimento válido no currículo de um curso de Pedagogia de uma instituição pública do Rio de Janeiro. Baseadas na teoria pós-crítica de currículo assumindo a tríade: currículo, conhecimento e cultura, defendem que a realização do currículo de Pedagogia ocorre como uma produção contingente e fluida. Mas não é o que encontram na grade curricular e ementas que analisaram. As autoras confirmam seus pressupostos de que os saberes disciplinares enfrentam desafios epistemológicos para sobreviverem na licenciatura em Pedagogia dada a característica generalista da formação. Mesmo as disciplinas classificadas como didáticas específicas possuem caráter estritamente pedagógico, quando deveriam repousar na produção científica das diferentes áreas do conhecimento humano e na sua relação com práticas pedagógicas inovadoras.

A partir da concepção pós-estruturalista e da teoria do discurso de Ernesto Laclau 4 , Oliveira (2015) propõe analisar a identidade da História nas políticas curriculares de 1960 a 2010, nos PCNS e nas Dire-

Educação \& Realidade, Porto Alegre, v. 43, n. 4, p. 1693-1723, out./dez. 2018.1699 
trizes Curriculares Nacionais para o Ensino Médio (DCNEM). A autora argumenta que sendo o campo do currículo uma prática de significação de atribuição de sentidos, é tempo de reconhecer a provisoriedade do conhecimento histórico e de seu próprio currículo, mas sem abrir mão da historicidade. Para a autora, os anos anteriores a 2000 foram marcados pela ausência da disciplina ou por metanarrativas estáticas que buscavam um ensino especializado, incompatível com a era atual: pós-moderna.

Na pesquisa de Santos (2015) há um olhar peculiar na busca pelo ensino de História nos espaços e tempos escolares para além da reprodução, mas como palco pedagógico de pesquisa e construção de novos conhecimentos históricos. A ideia é praticar uma alternativa curricular ao que vem sendo desenvolvido no nível oficial e denunciado como currículo mínimo. Só assim o espaço das políticas curriculares se concretizaria como mecanismo pedagógico de emancipação humana.

Ao final deste inventário percebe-se uma divisão de concepções teóricas para os diversos níveis de currículo e para o ensino de História. Antes dos anos 2000 imperavam as análises críticas de base marxista - geralmente apontando a integração via interdisciplinaridade como condição para a implantação de uma proposta integrada - e, após a virada do milênio, intensificaram-se os discursos pós-críticos e pós-estruturalistas nas pesquisas do campo curricular, relativizando os saberes objetivos e a própria crítica ao sistema capitalista, que tem como categorias centrais de análise: a cultura, o conhecimento e o cotidiano.

Para Young (2014, p. 192), esse embate resulta na fragilidade dos discursos dos especialistas em currículo e no não reconhecimento de sua autoridade intelectual:

$$
\begin{aligned}
& \text { Aqueles que detêm o poder político em geral não reconhe- } \\
& \text { cem a autoridade do conhecimento dos especialistas em } \\
& \text { currículo. Essa falta de reconhecimento é parcialmente } \\
& \text { por nossa culpa: há pouco acordo entre os especialistas } \\
& \text { em currículo sobre qual deveria ser o objeto de sua teoria. }
\end{aligned}
$$

Em outro texto Young (apud Galian; Louzano, 2014, p. 1116) lamenta a fragilidade atual da maioria das pesquisas em currículo e percebe que isso é resultado da fragilidade teórica dos cursos de formação de professores:

[...] os políticos responsáveis pelo estabelecimento do currículo nacional não prestam a menor atenção ao que dizem os teóricos do currículo, porque estes não têm nada a dizer. E, portanto, desenvolvem-se currículos frágeis, formulados por políticos e seus assessores, sem nenhum conhecimento especializado, porque eles não querem ouvir os teóricos do currículo.

Destarte, as últimas visões epistemológicas consolidaram o pós-estruturalismo e o olhar pós-crítico como elementos sedimentares nas políticas curriculares desde os anos 2000. Basta ampliar o olhar sobre muitas orientações e diretrizes curriculares que assumem essa posição 
e perceber que não carregam fortes elementos dessa perspectiva de currículo como a adesão ao multiculturalismo sem a devida crítica (Malanchen, 2016), e tampouco fazem o uso de conceitos como identidade, diferença, discurso e poder. Nota-se que as categorias currículo e integração/interdisciplinaridade foram as mais debatidas, porém, percebe-se como as análises se restringiram a debates teóricos de pouco progresso para fomentar práticas curriculares inovadoras que, de fato, consolidem o sistema curricular, para além de uma lista de conteúdos.

Embora cada produção tenha mérito no contexto em que fora escrita, a contemporaneidade revela que os especialistas de currículo devem ter preocupações para além dos debates meramente teóricos, sem o anseio de didatizar os conhecimentos por eles produzidos. Isso não significa abandonar a epistemologia em voga, tampouco consolidar análises acadêmicas que privilegiem puramente o pragmatismo; antes a teoria deve ser uma análise parcial da realidade, em se tratando de currículo, se o mesmo não for uma reflexão sobre a prática, como também defende Sacristán (2000), torna-se complexo almejar que acadêmicos e entidades comprometidas com a educação sejam ouvidos, a ponto de balancear as políticas públicas para a área.

\section{A Relacão entre o Currículo e a Didática nos Trabalhos do Endipe}

A tríade: currículo, didática e avaliação compõe as bases epistemológicas do processo da prática pedagógica. Embora esta pesquisa não esteja abrigada no campo da didática ou da avaliação, sabe-se que o processo de ligação entre o currículo e esses outros campos é dinâmico, intrínseco e sua separação não tem sentido (Freitas, 1998), embora cada um precise de um espaço curricular disciplinar específico que atenda às suas demandas, já que o currículo:

[...] tem uma preocupação com a organização global do
trabalho pedagógico (na escola ou fora dela) que constrói
outros parâmetros para o debate do método e da técnica.
Uma transferência direta, sem passar pela área de currí-
culo, entre os pressupostos filosóficos e a didática é desa-
conselhável, pois termina simplificando a questão peda-
gógica e supervalorizando aspectos relativos ao método
(Freitas, 1998, p. 39-40).

A compreensão do conhecimento produzido a partir da ligação entre as categorias centrais de um e de outro é o objeto de estudo dos pesquisadores que participam e debatem seus conhecimentos nas Reuniões Anuais do Encontro Nacional de Didática e Práticas de Ensino (Endipe). Nesse sentido, o que se propõe neste item é examinar como o objeto de estudo dessa pesquisa foi pensado ao longo de tais Encontros de Pesquisa, a partir dos resumos dos trabalhos (comunicações orais e pôsteres) publicados nos anais dos eventos desde 1982. À exceção de Simpósios, sessões especiais e mesas-redondas que têm o texto na íntegra disponível e foram, portanto, analisados.

Educação \& Realidade, Porto Alegre, v. 43, n. 4, p. 1693-1723, out./dez. 2018.1701 
Relaciona-se abaixo os textos publicados nos Anais e livros dos Encontros, desde o I Seminário A Didática em Questão/1982 até o evento ocorrido em 2014 na cidade de Fortaleza, Ceará. Os seguintes encontros não estão disponíveis para consulta: I Endipe/1979; VI Endipe/1991; V Endipe/1989; IV Endipe/1987 e os trabalhos do XVIII Endipe realizado na cidade de Cuiabá, Mato Grosso, entre os dias 23 a 26 de agosto de 2016 que não foram disponibilizados até o fechamento desta pesquisa. Foram usados os seguintes termos indutores para a captação dos títulos e a análise dos trabalhos (cabe acrescentar que alguns termos foram detalhados porque o evento está no âmbito da didática e infere-se que poderiam povoar alguns dos títulos das pesquisas): Pedagogia, currículo integrado, interdisciplinaridade e ensino de História.

Ao todo são 44 (quarenta e quatro) textos classificados em comunicações orais e mesas-redondas. Após a tabela descritiva (Tabela 2), serão explorados em sua completude a partir das temáticas que os une.

Tabela 2 - Distribuição Temporal dos Trabalhos Catalogados por Ano de Publicação - Endipe (continua)

\begin{tabular}{|c|c|c|c|}
\hline Ano & $\begin{array}{l}\text { Nome do } \\
\text { Evento }\end{array}$ & Título & Autor/es \\
\hline 1982 & $\begin{array}{l}\text { I Seminário “A } \\
\text { Didática em } \\
\text { Questão”. }\end{array}$ & Não foram captados trabalhos. & -------- \\
\hline 1983 & $\begin{array}{l}\text { II Encontro Na- } \\
\text { cional de Prá- } \\
\text { tica de Ensino } \\
\text { e "II Seminário } \\
\text { A didática em } \\
\text { Questão". }\end{array}$ & $\begin{array}{l}\text { 1. O Ensino de História no } 2^{\circ} \text { Grau: pro- } \\
\text { blemas, deformações e perspectivas. }\end{array}$ & 1. Elza Nadai \\
\hline 1985 & $\begin{array}{l}\text { III Encontro } \\
\text { Nacional de } \\
\text { Prática de } \\
\text { Ensino e “III } \\
\text { Seminário A } \\
\text { Didática em } \\
\text { Questão”. }\end{array}$ & Não foram captados trabalhos. & 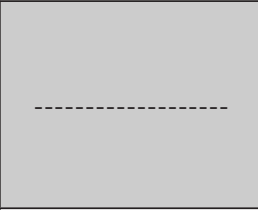 \\
\hline 1994 & $\begin{array}{l}\text { VII ENDIPE } \\
\text { "Produção do } \\
\text { conhecimento } \\
\text { e trabalho } \\
\text { docente" }\end{array}$ & $\begin{array}{l}\text { 1. Estudos Sociais no Ensino Funda- } \\
\text { mental na Rede Pública Municipal de } \\
\text { Goiânia. } \\
\text { 2. OEnsino de Histórianas Séries Iniciais } \\
\text { do } 1^{\circ} \text { Grau. } \\
\text { 3. A concepção de História no Ensino } \\
\text { Fundamental: noções de tempo e sujeito } \\
\text { histórico. } \\
\text { 4. Mudanças Históricas/ Mudanças no } \\
\text { Ensino de História. }\end{array}$ & $\begin{array}{l}\text { 1. Ângela Cristina B. } \\
\text { Mascarenhas } \\
\text { 2. Maria de Fátima } \\
\text { Salum Moreira } \\
\text { 3. José Ricardo Oriá } \\
\text { Fernandes } \\
\text { 4. Ubiratan Rocha } \\
\text { / Arlette M. Gaspa- } \\
\text { rello e Sônia Maria } \\
\text { Nikitiuk }\end{array}$ \\
\hline
\end{tabular}


Silva; Borges

\begin{tabular}{|c|c|c|c|}
\hline Ano & $\begin{array}{c}\text { Nome do } \\
\text { Evento }\end{array}$ & Título & Autor/es \\
\hline 1996 & $\begin{array}{l}\text { VIII ENDIPE } \\
\text { “Formação e } \\
\text { profissionali- } \\
\text { zação do edu- } \\
\text { cador”. }\end{array}$ & $\begin{array}{l}\text { 1. Por uma Teoria da Prática de Ensino } \\
\text { de História. } \\
\text { 2. Interdisciplinaridade nas Séries Ini- } \\
\text { ciais: considerações epistemológicas } \\
\text { e didáticas a partir de uma disciplina. } \\
\text { 3. Interdisciplinaridade: uma proposta } \\
\text { de ensino através de temas geradores. } \\
\text { 4. Construindo o currículo numa visão } \\
\text { interdisciplinar } \\
\text { 5. O Ensino da História e da Geografia: o } \\
\text { método e o conteúdo. } \\
\text { 6. Didática e Currículo: continuando o } \\
\text { diálogo. } \\
\text { 7. A Questão Pedagógica na Formação } \\
\text { de Professores. }\end{array}$ & $\begin{array}{l}\text { 1. Solange Ramos de } \\
\text { Andrade David } \\
\text { 2. Jane Bittencourt } \\
\text { 3. Marly Maria San- } \\
\text { tos Pinto } \\
\text { 4. Ana Paula Manci- } \\
\text { ni/ Lucrécia Mello } \\
\text { 5. Katarina Maria C. } \\
\text { Martins } \\
\text { 6. José Luiz Domin- } \\
\text { gues } \\
\text { 7. Dermeval Saviani }\end{array}$ \\
\hline 1998 & $\begin{array}{l}\text { IXENDIPE } \\
\text { "Olhando a } \\
\text { qualidade do } \\
\text { ensino a par- } \\
\text { tir da sala de } \\
\text { aula". }\end{array}$ & $\begin{array}{l}\text { *Mesa-Redonda: Multiculturalismo, } \\
\text { Currículo e Formação de Professores. } \\
\text { 1. Interdisciplinaridade: condição es- } \\
\text { sencial para uma prática de ensino } \\
\text { significativa. } \\
\text { 2. O processo de elaboração conceitual } \\
\text { no ensino de História e Geografia nas } \\
\text { séries iniciais da escolaridade. } \\
\text { 3. Interdisciplinaridade na formação dos } \\
\text { professores. Porto Velho - RO. }\end{array}$ & $\begin{array}{l}\text { * Antonio Flávio } \\
\text { Moreira } \\
\text { 1. Gelcivânia Mota } \\
\text { Silva Morais-UNEB } \\
\text { 2. Priscila Ribeiro } \\
\text { Ferreira-UFSC } \\
\text { 3. Derly Barbosa et } \\
\text { al. }\end{array}$ \\
\hline 2000 & $\begin{array}{l}\text { XENDIPE } \\
\text { "Ensinar e } \\
\text { aprender: } \\
\text { sujeitos, sabe- } \\
\text { res, espaços e } \\
\text { tempos". }\end{array}$ & $\begin{array}{l}\text { 1. Formação da consciência histórica na } \\
\text { escola básica: o papel dos currículos e } \\
\text { programas. } \\
\text { 2. Currículo integrado: uma construção } \\
\text { de sujeitos, um processo e uma práxis. } \\
\text { 3. O saber histórico escolar: entre o } \\
\text { universal e particular (construindo di- } \\
\text { ferenças e verdades através de história). } \\
\text { 4. Currículo emergente e aprendizagens } \\
\text { docentes no Curso de Pedagogia. }\end{array}$ & $\begin{array}{l}\text { 1. Kátia Maria Abud } \\
\text { - USP } \\
\text { 2. Regina Aurora } \\
\text { Trino Romano - } \\
\text { UERJ } \\
\text { 3. Carmen Teresa } \\
\text { Gabriel-PUC-Rio } \\
\text { 4. Vânia Beatriz } \\
\text { Monteiro da Silva } \\
\text {-UFSC }\end{array}$ \\
\hline 2002 & $\begin{array}{l}\text { XI ENDIPE } \\
\text { "Igualdade e } \\
\text { diversidade na } \\
\text { educação". }\end{array}$ & $\begin{array}{l}\text { 1. Políticas curriculares para a formação } \\
\text { de professores das séries iniciais do en- } \\
\text { sino fundamental: múltiplas interações } \\
\text { entre texto e contexto. } \\
\text { 2. Diretrizes Curriculares Nacionais para } \\
\text { a Formação de professores e o modelo } \\
\text { pedagógico de competências. } \\
\text { 3. A produção brasileira sobre integração } \\
\text { curricular (anos } 80 \text { e 90). } \\
\text { 4. Transversalidade na educação: uma } \\
\text { possibilidade } \\
\text { significativa para tornara educação mais } \\
\text { dinâmica e oportuna. } \\
5 \text {. A educação superior e suas relações } \\
\text { com a teoria curricular. } \\
\text { 6. Interdisciplinaridade no ensino: } \\
\text { problema metodológico ou questão } \\
\text { histórica. } \\
\text { 7. As concepções de transversalidade, } \\
\text { interdisciplinaridade e transdisciplina- } \\
\text { ridade (tit) como basepara a nova forma- } \\
\text { ção de profissionais da educação básica. }\end{array}$ & $\begin{array}{l}\text { 1.Arlete Maria Mon- } \\
\text { te Camargo } \\
\text { 2. Heloisa Helena O. } \\
\text { de Azevedo/ Adelei } \\
\text { Hilda Marques Ter- } \\
\text { ciotti-UNIMEP } \\
\text { 3. Leila Camelo dos } \\
\text { Santos / Alice Casi- } \\
\text { miro Lopes - NEC } \\
\text { - FE / UFRJ } \\
\text { 4. Álvaro Sebastião } \\
\text { Teixeira Ribeiro } \\
\text { 5. Hilton Fabiano } \\
\text { Boaventura Serejo } \\
\text { - PUC-MG } \\
\text { 6. José Luís Vieira } \\
\text { deAlmeida UNESP/ } \\
\text { UNINOVE } \\
\text { 7. Nali Rosa Silva } \\
\text { Ferreira / Dácio } \\
\text { Guimarães de } \\
\text { Moura }\end{array}$ \\
\hline
\end{tabular}

Educação \& Realidade, Porto Alegre, v. 43, n. 4, p. 1693-1723, out./dez. 2018.1703 
Currículo e Ensino de História

\begin{tabular}{|c|c|c|c|}
\hline Ano & $\begin{array}{l}\text { Nome do } \\
\text { Evento }\end{array}$ & Título & Autor/es \\
\hline 2004 & $\begin{array}{l}\text { XII ENDIPE } \\
\text { "Conhecimen- } \\
\text { to universal e } \\
\text { conhecimento } \\
\text { local". }\end{array}$ & $\begin{array}{l}\text { 1. Saberes e práticas avaliativas no ensi- } \\
\text { no de história. } \\
\text { 2. A produção do conhecimento a partir } \\
\text { da pedagogia de projetos: as múltiplas } \\
\text { possibilidades da interdisciplinaridade } \\
\text { em compasso com os temas transversais. } \\
\text { 3. A interdisciplinaridade e o currículo } \\
\text { disciplinar: } \\
\text { limites teórico-práticos dessa relação. }\end{array}$ & $\begin{array}{l}\text { 1. Zeli A. de Oliveira } \\
\text { / Selva G. Fonseca } \\
\text { - UFU } \\
\text { 2. LidianeAparecida } \\
\text { Ferreira Mariano / } \\
\text { Lucrécia Stringhet- } \\
\text { ta Mello - UFMS } \\
\text { 3. Jocinete das Gra- } \\
\text { ças Figueiredo - } \\
\text { UEMT }\end{array}$ \\
\hline 2006 & $\begin{array}{l}\text { XIII ENDIPE } \\
\text { "Educação, } \\
\text { Questões } \\
\text { Pedagógicas } \\
\text { e Processos } \\
\text { Formativos: } \\
\text { compromisso } \\
\text { com a inclusão } \\
\text { social". }\end{array}$ & $\begin{array}{l}\text { 1. Currículo de formação de professores } \\
\text { para séries iniciais do ensino fundamen- } \\
\text { tal: uma reflexão sócio-histórica. } \\
\text { 2. Formação de professores: uma pers- } \\
\text { pectiva interdisciplinar. }\end{array}$ & $\begin{array}{l}\text { 1. Márcia Maria } \\
\text { Gurgel Ribeiro - } \\
\text { UFRN } \\
\text { 2. Vanilda Maria } \\
\text { SantosTeófilo-USU }\end{array}$ \\
\hline 2008 & $\begin{array}{l}\text { XIV ENDIPE } \\
\text { "Trajetórias } \\
\text { e Processos } \\
\text { de Ensinar e } \\
\text { Aprender: luga- } \\
\text { res, memórias } \\
\text { e culturas". }\end{array}$ & $\begin{array}{l}\text { *Mesa-redonda: O conceito de interdis- } \\
\text { ciplinaridade e a cultura universitária. } \\
\text { **Mesa-redonda: Interdisciplinaridade } \\
\text { transdisciplinaridade: visões culturais } \\
\text { e epistemológicas e as condições de } \\
\text { produção. } \\
\text { *** Mesa-redonda: Memória, cultura, } \\
\text { identidades e desafios do curso de pe- } \\
\text { dagogia. } \\
\text { go** Mesa-redonda: A formação do peda- } \\
\text { 1. Ser professor de história para crianças. }\end{array}$ & $\begin{array}{l}\text { *Ari Paulo Jantsch } \\
\text { ** Ivani Catarina } \\
\text { Arantes Fazenda } \\
* * * \text { Iria Brzezinski } \\
\text { ****Leda Scheibe } \\
\text { 1. Grinaura Medei- } \\
\text { ros de MORAIS - } \\
\text { UFRN }\end{array}$ \\
\hline 2010 & $\begin{array}{l}\text { XV ENDIPE } \\
\text { "Convergên- } \\
\text { cias e tensões } \\
\text { no campo da } \\
\text { formação e } \\
\text { do trabalho } \\
\text { docente: polí- } \\
\text { ticas e práticas } \\
\text { educacionais". }\end{array}$ & $\begin{array}{l}\text { 1. O professor e a história ensinada e } \\
\text { aprendida nos Anos Iniciais do Ensino } \\
\text { Fundamental: trilhas a percorrer. }\end{array}$ & $\begin{array}{l}\text { 1. Sandra Regina } \\
\text { Ferreira deOliveira - } \\
\text { UEL / Ernesta Zam- } \\
\text { boni UNICAMP / } \\
\text { Flávia Heloísa Cai- } \\
\text { mi - UPF }\end{array}$ \\
\hline 2012 & $\begin{array}{l}\text { XVI ENDIPE } \\
\text { "Didática } \\
\text { e Práticas } \\
\text { de Ensino: } \\
\text { compromisso } \\
\text { com a escola } \\
\text { pública, laica, } \\
\text { gratuita e de } \\
\text { qualidade". }\end{array}$ & $\begin{array}{l}\text { 1. O cuidado interdisciplinar em um } \\
\text { currículo de formação docente. } \\
\text { 2. Formação de professores nas teses } \\
\text { sobre o currículo de pedagogia no Brasil. } \\
\text { 3. Interdisciplinaridade e formação de } \\
\text { pedagogos: aprendizagens da constru- } \\
\text { ção de uma experiência na educação } \\
\text { superior em Sobral-Ceará. } \\
\text { 4. Ensino dehistória na formação de pro- } \\
\text { fessores para as sériesiniciais e educação } \\
\text { de jovens, adultos e idosos. }\end{array}$ & $\begin{array}{l}\text { 1. Valda Inês Fonte- } \\
\text { nele Pessoa - Ufac } \\
\text { 2. Carolina Nozella } \\
\text { Gama / Cláudio De } \\
\text { Lira Santos Junior } \\
\text { 3. Eveline Andrade } \\
\text { Ferreira } \\
\text { 4. Rosilda Benác- } \\
\text { chio - UFF }\end{array}$ \\
\hline
\end{tabular}

1704 Educação \& Realidade, Porto Alegre, v. 43, n. 4, p. 1693-1723, out./dez. 2018. 


\begin{tabular}{|c|c|c|c|}
\hline Ano & $\begin{array}{c}\text { Nome do } \\
\text { Evento }\end{array}$ & Título & Autor/es \\
\hline 2014 & $\begin{array}{l}\text { XVII ENDIPE/ } \\
\text { FORTALEZA } \\
\text { "A Didática } \\
\text { e a Prática } \\
\text { de Ensino } \\
\text { nas relações } \\
\text { entre escola, } \\
\text { formação de } \\
\text { professores e } \\
\text { sociedade". }\end{array}$ & $\begin{array}{l}\text { 1. Eixo Estruturante e Transversalidade: } \\
\text { elementos orientadores dos currículos } \\
\text { da formação de profissionais da edu- } \\
\text { cação. } \\
\text { 2. Temas transversais e ensino dehistória } \\
\text { nos primeiros anos de escolarização. }\end{array}$ & $\begin{array}{l}\text { 1. Lívia Freitas Fon- } \\
\text { seca-UnB } \\
\text { 2. Lia Machado Fiu- } \\
\text { za Fialho - UEC / } \\
\text { Charliton José dos } \\
\text { Santos Machado - } \\
\text { UFPB }\end{array}$ \\
\hline
\end{tabular}

Fonte: Elaborada pelos autores.

Dos 44 (quarenta e quatro) artigos lidos, houve a catalogação por meio dos seguintes assuntos: pedagogia somam 7 (sete), currículo e currículo integrado são 6 (seis), interdisciplinaridade contam 12 (doze). Duas peculiaridades desse catálogo chamaram a atenção: o ensino de História obteve o maior número de pesquisas: 15 (quinze) e a presença de 4 (quatro) textos que discutiram um currículo integrado para a Pedagogia, esses últimos terão uma importância maior, pois dialogam com parte do presente objeto de pesquisa.

\section{Pedagogia}

Saviani (1996) sugere a apropriação crítica dos saberes a partir dos livros didáticos usados na educação básica para superar o dilema dos modelos de formação de professores descritos por ele como sendo modelo dos conteúdos culturais-cognitivos, cuja estrutura está centrada no ensino de cultura geral e de conhecimentos específicos. O outro, o modelo pedagógico-didático, sagra a docência como base, porém se preocupa de maneira superficial com os conhecimentos próprios das diferentes áreas de domínio destinadas para os pedagogos.

O debate sobre as influências das legislações nacionais como a LDB/96 (Brasil, 1996) e as Diretrizes Curriculares Nacionais para a Formação de Profissionais da Educação (Brasil, 2002) povoa os textos de Camargo (2002), Azevedo e Terciotti (2002) e Ribeiro (2006). Elas esclarecem que estas leis impulsionaram uma nova configuração para os currículos nos cursos de licenciatura, mas também frisam que a ANFO$\mathrm{PE}^{5}$ conseguiu trazer a docência como eixo organizador dessas propostas curriculares. As autoras são unânimes ao identificar que a formação docente ainda sofre com os resquícios dos princípios da racionalidade técnica que marcaram os anos de 1970 no Brasil.

Brzezinski (2008) tem como objetivo central em seu texto discutir a cultura organizativa do curso de Pedagogia diante das prováveis identidades do pedagogo que revelam contradições entre o estatuto epistemológico da ciência pedagógica e as visões de currículo presentes nas políticas reformistas impostas ao curso. A pesquisadora toma as DCN'S para a Pedagogia (Brasil, 2006) como eixo norteador para defender a docência como a base desses cursos, assim como Scheibe (2008) e a necessidade em romper com o etapismo nos currículos dos cursos 
(de Pedagogia). O grande desafio contemporâneo é elaborar propostas curriculares com base em núcleos temáticos, mas sem perder de vista a questão central que fomenta o debate e permanece sem uma resposta plausível: "A identidade do pedagogo dos anos 2000 se configura como professor-pesquisador-gestor?" (Scheibe, 2008, p. 224).

Gama e Junior (2012) analisam 14 (catorze) teses de doutorado entre os anos de 1987 e 2010 a partir das expressões: currículo de Pedagogia e currículo do curso de Pedagogia. A investigação apontou que $86 \%$ das teses fundamentam-se numa visão idealista de homem, centrando a discussão do currículo na subjetividade. Elas discutem o currículo sem considerar que suas mudanças devem estar ligadas à luta pela superação da realidade que o determina. $14 \%$ (catorze por cento) das outras teses sustentam-se a partir do materialismo numa concepção de formação baseada no trabalho e em defesa de um projeto socialista de Estado.

\section{Currículo e Currículo Integrado}

No texto de Domingues (1996), há o histórico embate entre currículo e didática. $\mathrm{O}$ autor define que em um sistema educativo centralizado, a discussão tende a tomar partido de um dos campos. No Brasil a tendência acadêmica é basear os escritos em didática na tradição alemã e os de currículo na vanguarda norte-americana.

A pesquisa apresentada por Moreira (1998) argumenta que a formação docente deve centrar-se numa perspectiva curricular multicultural crítica, e só assim avançará nos debates com as realidades concretas e díspares do Brasil. O objetivo de todo currículo crítico é ir contra toda forma de discriminação.

Romano (2000) diz que o currículo integrado é a melhor maneira de promover uma formação completa para enfermeiros que supere a fragmentação dos saberes na saúde. Já a reflexão de Silva (2000) narra as práticas multidisciplinares no currículo de Pedagogia da Universidade Federal de Santa Catarina (UFSC), tendo como eixos a docência e as diferentes habilitações, salientando que o sucesso das aulas está na adesão aos projetos de ensino.

A síntese de Santos e Lopes (2002) busca capturar os diferentes conceitos de currículo integrado empregados nos textos acadêmicos do Brasil nos anos 1980 e 1990. O estudo trouxe tipos como: currículo interdisciplinar, transdisciplinar, transversal, em rede e por projetos. Segundo as autoras, o maior problema que cerca os mais variados tipos de currículos integrados praticados é a formação incipiente de professores para lidar com eles.

Serejo (2002) tenta compreender quais teorias de currículo baseadas na divisão de Tomaz Tadeu da Silva predominam nas universidades brasileiras. A pesquisa denunciou a soberania das teorias tradicionais nas instituições públicas e privadas e um emergente crescimento das teorias pós-críticas nas universidades públicas. A teoria crítica encontra-se em fase de desaceleração na realidade pesquisada pelo autor. Talvez

1706 Educação \& Realidade, Porto Alegre, v. 43, n. 4, p. 1693-1723, out./dez. 2018. 
porque um dos grandes desafios para os teóricos críticos, segundo Libâneo (1998, p. 73), seja propor uma “[...] teoria curricular crítica, para além de uma Sociologia da Educação” que supere a suposta distância entre os campos do currículo e da didática. O pedagogo lança uma crítica e ao mesmo tempo um desafio para os teóricos da vertente crítica do currículo: "Os curriculistas críticos precisam empenhar-se mais em dar operacionalidade às suas propostas em vez de criticar os didatas por tentarem fazê-lo" (Libâneo, 1998, p. 76).

\section{Interdisciplinaridade}

Bittencourt (1996) toma a Matemática nas séries iniciais como ponto central para promover a verdadeira interdisciplinaridade que se caracteriza em estudar um tema central, seus desdobramentos e construir a partir dele novos saberes, além dos que cercam as disciplinas. Proposta parecida está na pesquisa de Pinto (1996), de Mancini e Mello (1996). Para elas, a prática interdisciplinar só funciona se houver interdependência, interação e comunicação com os sujeitos implicados na moldagem do currículo, sendo que a saída para as teóricas é a execução de aulas baseadas em temas geradores ou na pedagogia de projetos, como revelou também o estudo de Mariano e Mello (2004).

O Estágio Supervisionado interdisciplinar no curso de Pedagogia é a aposta de Morais (1998) para construir um saber unificado da graduação até os anos iniciais. Barbosa et al. (1998) reconhecem que assim será possível recuperar uma formação humana integral na escola. Visão similar à do artigo de Figueiredo (2004), que baseia seus escritos nos Estudos Culturais e em Michel Foucault para investigar a concepção de interdisciplinaridade no Projeto Coletivo de Estágio Supervisionado das Licenciaturas da Universidade do Estado de Mato Grosso (UNEMAT). Para ela, a presença da disciplina currículo em todos os cursos facilitou as práticas no estágio, ainda assim, a divisão entre saberes materializada nos departamentos das faculdades e institutos ainda é uma barreira a ser transposta.

Ribeiro (2002) traz a teoria da complexidade de Edgar Morin ${ }^{6}$ como possibilidade de abordagens mais dinâmicas e plurais com relação ao manuseio dos temas transversais presentes nos PCN'S. Ele defende que três ações pedagógicas garantem isso: problematizar, investigar e dialogar nos momentos formativos das instituições de ensino.

Almeida (2002), Moura e Ferreira (2002), Jantsch (2008) e Fazenda (2008) trazem uma discussão epistemológica da interdisciplinaridade, transversalidade e transdisciplinaridade e chegam às seguintes considerações: a) a interdisciplinaridade é um processo e uma postura desejada para os professores, contudo isso só acontecerá se em seus processos formativos houver o estudo aprofundado dos componentes essenciais para que ela ocorra: didática, currículo e avaliação (Almeida; 2002; Fazenda, 2008); b) a transversalidade aparece como brecha para aperfeiçoar a relação entre conteúdos e outras áreas para resultar em novas elaborações de conhecimentos na transdisciplinaridade (Mou-

Educação \& Realidade, Porto Alegre, v. 43, n. 4, p. 1693-1723, out./dez. 2018. 1707 
Currículo e Ensino de História

ra; Ferreira, 2002); c) complexidade e interdisciplinaridade são desdobramentos das categorias contradição e totalidade, respectivamente. Há objetos que só podem ser compreendidos na esfera interdisciplinar; outros se esgotam apenas se a pesquisa captar sua especificidade, portanto a interdisciplinaridade jamais pode ser concebida como elemento agregador para "[...] reduzir saberes diferentes a um denominador comum" (Jantsch, 2008, p. 152).

Em outra obra, Fazenda (2002) reflete que a interdisciplinaridade da forma como vem sendo praticada no Brasil trava em três tipos de obstáculos: no caráter metodológico, no caráter formativo e no caráter operacional (infraestrutura física dos prédios escolares) porque, segundo a autora:

\begin{abstract}
A interdisciplinaridade vem sendo utilizada como 'panaceia' para os males da dissociação do saber, a fim de preservar a integridade do pensamento e do estabelecimento de uma ordem perdida [...] Interdisciplinaridade possibilita a eliminação do hiato existente entre a atividade profissional e a formação escolar (Fazenda, 2002, p. 8-41).
\end{abstract}

\title{
Ensino de História
}

Os artigos de Nadai (1983), Martins (1996) e Mascarenhas (1994) repercutem as dificuldades em ministrar aulas de História no ensino fundamental nas décadas de 1980 e 1990: falta de autonomia intelectual dos estudantes em fazer análises interpretativas da disciplina, com o agravante de o ensino permanecer baseado em datas, fatos e heróis nacionais. David (1996), Benácchio (2012) e Ferreira (1998) lembram ainda que, antes de ensinar técnicas e métodos para essa disciplina, é preciso compreender sua teoria e seu método de pesquisa e de produção de conhecimento. Polêmica semelhante está presente em Fernandes (1994), Moreira (1994) e Gasparello e Nikitiuk (1994), e segundo eles, para vencer esses obstáculos é necessário romper com a visão tradicional de História e de heróis nacionais e trabalhar com a concepção de que a História é um processo de construção coletiva.

Abud (2000), Gabriel (2000) e Fialho e Machado (2014) demonstram a vitalidade dos Parâmetros Curriculares Nacionais para o Ensino Médio (PCNEM) em somar para a consolidação de uma formação histórica nos jovens, desde que a pluralidade e a diversidade sociocultural apareçam como elementos estruturadores destes currículos. Fato que, segundo Oliveira e Fonseca (2004), garantem uma prática avaliativa crítica e emancipatória.

As autoras Oliveira, Zamboni e Caimi (2010) discutem como garantir uma sólida formação na História para os pedagogos. Já Morais (2008) anuncia que a História a ser ensinada nos anos iniciais pode ser interessante, construtiva e prazerosa se as seguintes habilidades forem consideradas nas aulas: "[...] desenvolvimento do pensamento autônomo e crítico do aluno por meio da memorização, observação, investigação, compreensão, interpretação, comparação, argumentação, análise, síntese e generalização" (Morais, 2008, p. 6).

1708 Educação \& Realidade, Porto Alegre, v. 43, n. 4, p. 1693-1723, out./dez. 2018. 


\section{Currículo integrado para a Pedagogia}

Na pesquisa de Teófilo (2006, p. 1) existe o apontamento de que:

[...] as experiências implementadas nos cursos de formação de licenciados ainda não são suficientes para garantir a integração dos saberes - científico e pedagógico. O currículo, as teorias e práticas, as metodologias são mexidas, mas ainda assim continuamos sem resolver a contento os problemas e dificuldades inerentes a essa formação.

Por exemplo, os cursos de Pedagogia ainda estão centrados na linearidade do conhecimento. Para romper esse paradigma o currículo deveria integrar as bases que formam o próprio curso: História, Psicologia, Filosofia e o campo educativo.

Em Pessoa (2012) e Ferreira (2012) há orientações e caminhos a serem trilhados. Eles podem reverberar em práticas curriculares interdisciplinares: parceria e registro dos docentes, ludicidade, oficinas pedagógicas, literatura e avaliação emancipatória.

Por meio de uma síntese científica, Borges (2014) mergulha nos conceitos de eixo estruturante e transversalidade no campo curricular da formação de professores. As seguintes reflexões merecem destaque: necessidade em problematizar quando o que é transversal se torna estruturante; a tentativa insana de interdisciplinarizar currículos pelo Brasil, originando um docente superlotado e nem sempre um currículo disciplinar é um problema. Por fim, a autora elabora a ideia de um currículo onde a

[...] a transversalidade não se constitui em campo disciplinar, mas seus respectivos conteúdos integram o ementário e respectivas unidades temáticas dos planos de ensino [...] os currículos que orientam a formação dos profissionais da educação têm em seus eixos estruturantes os referenciais conceituais de base disciplinar de onde se produz a capilaridade materializada pela transversalidade (Borges, 2014, p. 1192-1197).

O levantamento anterior contribuiu para compreender como os teóricos de várias áreas têm discutido o ensino de História nos currículos, integrados ou não, dos cursos de Pedagogia. As seguintes constatações resumem isso: o campo do currículo no Brasil não se desligou das produções estrangeiras e ainda reproduz modelos incipientes para superar seus próprios impasses, item que foi confirmado pelos textos investigados na Anped; propor políticas educacionais e curriculares baseadas em experiências externas ao Brasil não se constitui um problema em si, mas, replicar práticas sem o devido cuidado adaptativo e contextual pode tornar-se um imbróglio maior ainda; a Pedagogia enquanto ciência padece de debates mais profundos sobre sua identidade e de como poderá formar os profissionais preconizados nas legislações não somente na docência, mas a partir dela. Na verdade, muitas pesquisas não têm se atentado ao fato de que a Pedagogia não tem uma identidade, mas múltiplas identidades.

Educação \& Realidade, Porto Alegre, v. 43, n. 4, p. 1693-1723, out./dez. 2018.1709 
Os modelos de integração pela interdisciplinaridade reduzem-se, seja na educação básica ou superior, em atitudes espaças e limitadas pela complexidade da epistemologia que se faz presente na própria interdisciplinaridade. Muitos textos apenas tentaram conceituar o termo, mas não tiveram a preocupação em propor saídas para as maiores dificuldades de pensar as formas de integração curricular, para além da mera justaposição de disciplinas e finalmente: a História ensinada em alguns cursos de Pedagogia até o momento sofre com o esvaziamento teórico e até mesmo metodológico descolados das próprias noções historiográficas e dos documentos curriculares que garantam o estudo da História na Pedagogia. A fragilidade se dá, em boa parte dos espaços analisados nas produções, pela pouca importância que as instituições que oferecem a licenciatura em Pedagogia dão ao ensino de História, além de não contarem, em grande maioria, com profissionais que dialogam bem com as duas vertentes desse ensino: estudar a História no universo escolar dos anos iniciais do ensino fundamental.

\title{
Artigos Acadêmicos Cadastrados na Rede SciELO
}

Foram analisados nesta seção artigos científicos completos cadastrados na Rede SciELO ${ }^{7}$ (Scientific Electronic Library Online). O espaço virtual de compartilhamento de periódicos foi criado em 1998. Uma publicação de 2014 traça a história e o perfil do programa:

\begin{abstract}
A Rede SciELO é o resultado de um programa de acesso aberto de cooperação internacional em comunicação acadêmica denominado programa SciELO. Em agosto de 2013, a rede já abrangia um total de dezesseis países: quinze ibero-americanos e a África do Sul (Packer; Cop; Santos, 2014, p. 41).
\end{abstract}

O portal brasileiro é o de maior abrangência entre os países membros. Atualmente estão cadastrados os 275 melhores periódicos de impactos do país nas mais diferentes áreas e com uma média de 12.000 artigos em Língua Portuguesa. A instituição que coordena os trabalhos aqui no Brasil é a Fundação de Apoio à Universidade Federal de São Paulo (FapUNIFESP).

A Rede conta com os seguintes critérios de escolha para aprovar os processos de indexação dos periódicos: avaliação da webqualis do CNPq; aspectos formais (conteúdo e forma do periódico); fluxo editorial; conteúdo científico; impacto e gestão editorial, o que garante a qualidade acadêmica dos artigos aqui analisados. Ressalte-se que a opção por deter o olhar nesta Rede de Armazenamento Eletrônico não exclui a possibilidade de, ao longo deste trabalho, fundamentar ideias baseadas em textos acadêmicos publicados em outros periódicos que não estejam abrigados no SciELO.

É o caso da Revista Currículo Sem Fronteiras ${ }^{8}$, que tem como intenção ser um espaço para a discussão de uma educação crítica e emancipatória, reforçando o diálogo entre os países de Língua Portuguesa. A

1710 Educação \& Realidade, Porto Alegre, v. 43, n. 4, p. 1693-1723, out./dez. 2018. 
Silva; Borges

publicação eletrônica oferece edições desde 2001 e seu editorial é coordenado pelos professores Álvaro Moreira Hypolito, João Paraskeva e Luís Armando Gandin.

Para esta seção foram catalogados para estudo o conjunto de 18 (dezoito) artigos acadêmicos brasileiros abrigados no grande campo da Educação a partir dos termos: Pedagogia, currículo integrado, interdisciplinaridade e ensino de História desde que a plataforma ScIELO foi criada aqui no Brasil (Tabela 3 ).

\section{Tabela 3 - Distribuição dos Trabalhos Captados por Título, Autor e Ano de Publicação na Rede SciELO (continua)}

\begin{tabular}{|c|c|c|}
\hline Título do artigo & Autor/es & Ano de publicação \\
\hline $\begin{array}{l}\text { 1. Interdisciplinaridade: funcio- } \\
\text { nalidade ou utopia? }\end{array}$ & Maria Cecília de Souza Minayo & 1994 \\
\hline $\begin{array}{l}\text { 2. O conhecimento e a interdisci- } \\
\text { plinaridade: primeiras reflexões. }\end{array}$ & Antonio Lineu Carneiro et al. & 1994 \\
\hline $\begin{array}{l}\text { 3. Multidisciplinaridade, Interdis- } \\
\text { ciplinaridade e Transdisciplinari- } \\
\text { dade no Ensino. }\end{array}$ & Marília Freitas de Campos Pires & 1998 \\
\hline $\begin{array}{l}\text { 4. Representações e Linguagens no } \\
\text { Ensino de História. }\end{array}$ & Ernesta Zamboni & 1998 \\
\hline $\begin{array}{l}\text { 5. Formação Profissional: refle- } \\
\text { xões sobre a interdisciplinaridade. }\end{array}$ & $\begin{array}{c}\text { Maria Lúcia Toralles Pereira } \\
\text { / Miriam Celi Pimentel Porto } \\
\text { Foresti }\end{array}$ & 1998 \\
\hline $\begin{array}{l}\text { 6. Propostas curriculares alterna- } \\
\text { tivas: Limites e Avanços. }\end{array}$ & Antonio Flavio Barbosa Moreira & 2000 \\
\hline $\begin{array}{l}\text { 7. Currículo, cultura e formação } \\
\text { de professores. }\end{array}$ & Antonio Flavio Barbosa Moreira & 2001 \\
\hline $\begin{array}{l}\text { 8. O campo do currículo no Bra- } \\
\text { sil: construção no contexto da } \\
\text { ANPED. }\end{array}$ & Antonio Flavio Barbosa Moreira & 2002 \\
\hline $\begin{array}{l}\text { 9. O espaço Acadêmico da Pe- } \\
\text { dagogia no Brasil: perspectiva } \\
\text { histórica. }\end{array}$ & Dermeval Saviani & 2004 \\
\hline $\begin{array}{l}\text { 10. Interdisciplinaridade: uma } \\
\text { contextualização. }\end{array}$ & $\begin{array}{l}\text { Maria Lúcia Borges Gattás / An- } \\
\text { tonia Regina Ferreira Furegato }\end{array}$ & 2006 \\
\hline $\begin{array}{l}\text { 11. Diretrizes Curriculares Nacio- } \\
\text { nais da Pedagogia: imprecisões } \\
\text { teóricas e concepção estreita da } \\
\text { formação profissional de educa- } \\
\text { dores. }\end{array}$ & José Carlos Libâneo & 2006 \\
\hline $\begin{array}{l}\text { 12. Pedagogia: o espaço da educa- } \\
\text { ção na universidade. }\end{array}$ & Dermeval Saviani & 2007 \\
\hline $\begin{array}{l}\text { 13. Formação de professores: } \\
\text { aspectos históricos e teóricos do } \\
\text { problema no contexto brasileiro. }\end{array}$ & Dermeval Saviani & 2009 \\
\hline $\begin{array}{l}\text { 14. Estudos de Currículo: avanços } \\
\text { e desafios no processo de interna- } \\
\text { cionalização. }\end{array}$ & Antonio Flavio Barbosa Moreira & 2009 \\
\hline $\begin{array}{l}\text { 15. Currículo Integrado: entre o } \\
\text { Discurso e a Prática. }\end{array}$ & $\begin{array}{c}\text { Patrícia Alves de Souza / An- } \\
\text { gélica Maria Bicudo Zeferino/ } \\
\text { Marco Aurélio Da Ros }\end{array}$ & 2010 \\
\hline
\end{tabular}

Educação \& Realidade, Porto Alegre, v. 43, n. 4, p. 1693-1723, out./dez. 2018.1711 
Currículo e Ensino de História

\begin{tabular}{|l|c|c|}
\hline \multicolumn{1}{|c|}{ Título do artigo } & Autor/es & Ano de publicação \\
\hline $\begin{array}{l}\text { 16. Ensino de História hoje: errân- } \\
\text { cias, conquistas e perdas. }\end{array}$ & $\begin{array}{c}\text { Marcos Antônio da Silva / Selva } \\
\text { Guimarães Fonseca }\end{array}$ & 2010 \\
\hline $\begin{array}{l}\text { 17. Os novos sentidos da interdis- } \\
\text { ciplinaridade. }\end{array}$ & Otávio Velho & 2010 \\
\hline $\begin{array}{l}\text { 18. Interdisciplinaridade, entre o } \\
\text { conceito e a prática: Um estudo } \\
\text { de caso. }\end{array}$ & $\begin{array}{c}\text { Susana Cesco / Roberto José } \\
\text { Moreira / Eli de Fátima Napo- } \\
\text { leão de Lima }\end{array}$ & 2014 \\
\hline
\end{tabular}

Fonte: Elaborada pelos autores.

Saviani (2004) trouxe a necessidade de resgatar a tradição teórica do curso de Pedagogia no Brasil para reafirmar o status científico desta para além de ser uma ciência da prática. Em outras obras (Saviani, 2007; 2009), o filósofo estudou as Diretrizes Curriculares da Pedagogia (Brasil, 2006) e concluiu que só haverá ciência pedagógica nos espaços de formação inicial se as investigações resultarem em conceitos teóricos voltados para a prática social já que "[...] toda pedagogia é teoria da educação, nem toda teoria da educação é pedagogia” (Saviani, 2007, p. 102). A pedagogia precisa ir além das atuais diretrizes, deve tomar a disciplina de História, como eixo central e organizador dos currículos.

Libâneo (2006) trata das imprecisões conceituais e teóricas que as DCN'S provocaram no curso de Pedagogia (Brasil, 2006). Para ele, a legislação resultou num olhar estreito sobre a formação de profissionais da educação agora centrada na docência expressa por meio do termo contraditório do próprio documento: licenciatura em pedagogia. Libâneo (2006) é incisivo ao sugerir que as diretrizes têm fundamentação teórica precária, principalmente no que diz respeito ao campo conceitual da Pedagogia, ao trazer uma visão reduzida da própria ciência, pois nem todo pedagogo precisa ser docente. $O$ estudioso demonstra ainda que o inchaço do currículo causado pelas exigentes e diversas atribuições causa uma superficialidade nos processos formativos ao ponto de “[...] não se estudar pedagogia nos cursos de pedagogia” (Libâneo, 2006, p. 861).

Moreira (2000) aborda propostas curriculares que fugiram do discurso oficial hegemônico - baseado na pedagogia dos conteúdos ou na Educação Popular de Paulo Freire - nas décadas de 1980 e 1990. A implantação dos currículos em rede por meio de ações importantes, mas tímidas, como o uso de eixos transversais ou norteadores da rede pública municipal de ensino de São Paulo, os núcleos conceituais da rede municipal do Rio de Janeiro, a escola plural de Belo Horizonte e ainda a escola cidadã em Porto Alegre, trouxeram projetos mais integradores e com foco nos sujeitos em situação de vulnerabilidade. Isso é o resultado da influência das teorias pós-críticas de cunho pós-estruturalista nos processos de elaboração curriculares. Para o autor, essas experiências contribuíram para que o currículo fosse concebido como artefato que cumpre a função socializadora e cultural da escola e não uma lista de conteúdos determinados a priori. Com o lema de que não há desenvolvimento curricular se não houver ao mesmo tempo o desenvolvimento do professor, Moreira (2001) afirma que o espaço formativo dos profes-

1712 Educação \& Realidade, Porto Alegre, v. 43, n. 4, p. 1693-1723, out./dez. 2018. 
sores no Brasil deve levar em consideração o caráter político da prática pedagógica.

Nos textos de 2002 e 2009, Moreira faz dois inventários singulares: no primeiro, demonstra que o GT de currículo da Anped tornou-se um enfadonho espaço de passarela para trabalho, quando na verdade deveria ser um espaço privilegiado para fazer avançar o campo. A segunda reflexão aponta que as reuniões dos colóquios luso-brasileiros de questões curriculares contribuíram no avanço do campo para sua internacionalização a partir do cenário brasileiro.

Souza, Zeferino e Da Ros (2011) discutem as possíveis mudanças curriculares ocorridas nas escolas médicas contempladas com o Programa de Incentivo a Mudanças Curriculares nos Cursos de Medicina (Promed) e a política foi criada pelo Ministério da Saúde e da Educação. $\mathrm{O}$ artigo apresentou as mudanças de estrutura em algumas escolas, mas ponderou também que as concepções acadêmicas sobre integração precisam ser mais bem desenvolvidas. O currículo modular integrador foi o mais praticado pelas escolas e nele o centro da prática educativa é o estudante, que deve usar a problematização como mecanismo que interliga as diferentes áreas da medicina na resolução dos estudos de caso.

Minayo (1994) destaca que o termo interdisciplinaridade tem aparecido de maneira distorcida e tendenciosa nas pesquisas científicas brasileiras nos últimos vinte anos. Para ela, tem ocorrido uma verdadeira panaceia epistemológica. Por esse motivo, seu olhar detém-se nas contribuições conceituais de Gusdorf, Carneiro Leão e Habermas para justificar a utilidade de práticas investigativas entre áreas da Saúde. Percurso teórico similar ao artigo de Gattás e Furegatto (2006), as teóricas apuraram práticas interdisciplinares em cursos de Enfermagem e descobriram que integração nesse formato é muito mais discutida nesses espaços que praticada.

Os artigos de Carneiro et al. (1994) e Cesco, Moreira e Lima (2014) apresentam as ligações entre construção do conhecimento e interdisciplinaridade no Brasil sob o aspecto metodológico no que os autores denominaram de pedagogia da comunicação: ação teórica que garante intensa ligação entre campos diversos do conhecimento para construção de teses e dissertações nos programas de pós-graduação, principalmente nas áreas humanas.

Os escritos de Pires (1998) foram os únicos que colocaram em tela a necessidade da interdisciplinaridade nas práticas pedagógicas da educação básica na contramão da parcelarização do conhecimento imposto pelos currículos capitalistas. A autora diz que o caminho interdisciplinar é um problema, mas também uma necessidade, e lembra ainda que integração não significa justaposição de disciplinas, tampouco o abandono delas. Reflexão confirmada na obra de Luck (1994), onde se percebe a constituição teórica do que a autora denominou interdisciplinaridade plena para promover a superação da visão restrita de mundo e a compreensão da complexidade da vida, por parte de professores e es-

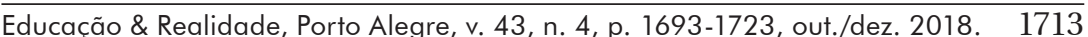


tudantes. Os primeiros precisam ir além da tecnificação e didatização híbrida da interdisciplinaridade.

Velho (2010) destaca que o século XX trouxe o paradigma científico da interdisciplinaridade e, mesmo com o êxito comprovado de áreas como a Biofísica e a Bioquímica, garantir a consolidação de práticas científicas inter demanda muitos pressupostos e ações como as enumeradas por Pereira e Foresti (1998): nem todo conhecimento exige tratamento interdisciplinar; não se avança nesta seara se não houver a superação da visão empirista e positivista de fazer ciência e, ainda, não se pode cair no reducionismo estruturalista ou mesmo na interdisciplinaridade superficial. Os escritos de Zamboni (1998) e Silva e Fonseca (2010) lembraram que as legislações curriculares do ano 2000 garantiram a História no ensino fundamental e promoveram a inserção de novas linguagens nessa etapa da educação básica, como a fotografia e as crônicas.

Dentre os 18 (dezoito) artigos pinçados para reflexão, quatro trataram de algum aspecto da Pedagogia: Saviani $(2004 ; 2007 ; 2009)$ e Libâneo (2006). Doze discorreram sobre currículo, sendo cinco sobre epistemologia do campo: Moreira (2000; 2001; 2002; 2009) e Souza, Zeferino e Da Ros (2011) e sete que trataram de interdisciplinaridade: Minayo (1994), Carneiro et al. (1994), Pires (1998), Pereira e Foresti (1998), Gattás e Furegato (2006), Velho (2010) e Cesco, Moreira e Lima (2014).

Destaca-se a ênfase dada pelos autores que trataram da integração de currículo ao conceberem a interdisciplinaridade sob o aspecto da pesquisa científica, da evolução do espírito científico e da própria produção de conhecimento em diferentes campos. Isso é essencial para a criação de currículos e programas que compreendam a epistemologia dos termos para fazer com que as práticas planejadas e executadas cumpram seu papel fundamental: a formação de sujeitos intelectuais e pensantes que dominem o conhecimento científico que foi acumulado pela humanidade, podendo utilizá-los em sua vida cotidiana, para além das meras exposições teóricas despreocupadas em consolidar uma formação verdadeiramente integrada. Apenas uma pesquisa traçou o paralelo entre epistemologia e polissemia do termo com a possibilidade de materialização em práticas pedagógicas na educação básica, o que revela a necessidade de mapear ações em curso que tentem imprimir essa nova forma de organização do trabalho pedagógico, para que se possa mensurar os retrocessos, os equívocos e os possíveis avanços que estejam ocorrendo.

Os teóricos mais citados foram: Japiassu (1976), Fazenda (2012), Frigotto (1995), Jantsch e Bianchetti (1995). Para somar o total de textos dessa seção, destacam-se dois: Zamboni (1998) e Silva e Fonseca (2010) ao relativizarem teses sobre as atualizações para o ensino de História no ensino fundamental e no ensino médio. 


\section{Reflexões: avanços no campo do currículo}

O conjunto dessas produções expressou o quanto a educação e o campo do currículo, no que diz respeito à integração via interdisciplinaridade, estiveram subsumidos. O mesmo ocorreu com o ensino de História, praticamente inexistente no SciELO. O destaque ocorreu nas pesquisas sobre o curso de Pedagogia, e embora centrassem suas inquietações na implementação das diretrizes curriculares (Brasil, 2006), relacionaram os impactos dessa normativa legal para ampliar e em alguns momentos reduzir a natureza epistemológica da própria Pedagogia e de seus diferentes currículos praticados pelo país. Provavelmente os textos desde 2016 trazem algum aspecto dos impactos que as novas diretrizes curriculares nacionais para a formação inicial em nível superior e para a formação continuada de profissionais da educação (Brasil, 2015) implicam no campo curricular.

Os textos estudados anteriormente, quando trataram de algum aspecto do currículo ou da formação dos pedagogos na interface com o ensino de História, denunciaram que o maior problema está na dificuldade curricular do professor pedagogo em ministrar aulas de disciplinas nas quais não se especializou e que, portanto, desconhece as especificidades teóricas e metodológicas dessas matérias, o que se reverterá em aulas de História com caráter factual e com forte apelo à memorização. As soluções apontadas pelas pesquisas são: permanente discussão em torno da formação dos pedagogos, desenvolvimento de uma política de pesquisa permanente na área de História para os primeiros anos de escolarização, como também um assessoramento específico nas disciplinas em que os professores de anos iniciais lecionam por meio de uma coordenação local para estudos e formação.

Assim, esta pesquisa aponta como saídas e propostas para futuras reflexões os seguintes temas, que ainda carecem de aprofundamento ou de renovação acadêmica, ao menos a partir do universo das instituições investigadas: a relevância da epistemologia para compreensão sobre a natureza da Pedagogia; a seara sob a qual os formadores de pedagogos têm de enfrentar, sobretudo na garantia de uma formação sólida para um profissional que será polivalente, caso opte pela docência nos anos inicias do ensino fundamental ou pelo primeiro segmento da Educação de Jovens e Adultos; formas de alinhar o currículo da formação com o de atuação no magistério; os desdobramentos sobre os diferentes níveis de integração curricular, para além da interdisciplinaridade; as características de um currículo anunciado como integrado; a relação entre os eixos transversais e estruturantes; o conhecimento necessário ao professor que ministra disciplinas ligadas ao ensino de História no curso de Pedagogia. São apenas apontamentos iniciais, que podem ser desdobrados e articulados de acordo com os anseios de pesquisa de cada pesquisador que se interesse em fazer com que o campo educacional e curricular avance.

Recebido em 26 de setembro de 2017 Aprovado em 20 de abril de 2018

Educação \& Realidade, Porto Alegre, v. 43, n. 4, p. 1693-1723, out./dez. 2018.1715 


\section{Notas}

1 Optou-se por inserir a referência bibliográfica dos textos analisados na forma de tabelas, dentro de cada seção, para garantir uma leitura mais dinâmica do artigo.

2 Disponível em: <http://www.anped.org.br/reunioes-cientificas/nacional>. Acesso em: 26 mar. 2016.

3 Ao longo do artigo são utilizadas as referências que estão em todas as tabelas de forma completa.

4 Para mais detalhes ver Laclau (2001).

5 Associação Nacional pela Formação de Professores: instituição criada em 26 de julho de 1990, em assembleia nacional do $5^{\circ}$ Encontro nacional da Comissão nacional de reformulação dos Cursos de Formação do Educador (Conarcfe), realizado em Belo Horizonte (MG) entre 24 a 27 de julho, tem como finalidade fazer avançar o conhecimento no campo da formação e da valorização dos profissionais da educação, por meio da mobilização de pessoas, de entidades e de instituições dedicadas a esta finalidade. Disponível em: $<$ http://www. fe.unicamp.br/anfope/menu2/links/arquivos/Estatuto_Anfope.pdf $>$. Acesso em: 30 maio 2016.

6 Para mais detalhes, ver Morin (2006).

7 Disponível em: <http://www.scielo.org/php/index.php?lang=pt>. Acesso em 05 abr. 2016.

8 Disponível em: <http://www.curriculosemfronteiras.org/index.htm>. Acesso em 18 abr. 2016.

\section{Referências}

ABREU, Rozana Gomes. A Concepção de Currículo Integrado e o Ensino de Química no Novo Ensino Médio. In: REUNIÃO ANUAL DA ASSOCIAÇÃO NACIONAL DE PÓS-GRADUAÇÃO E PESQUISA EM EDUCAÇÃO, 24., 2001, Caxambu. Anais... Caxambu, 2001. P. 01-08.

ABUD, Kátia Maria. Formação da Consciência Histórica na Escola Básica: o papel dos currículos e programas. In: ENDIPE - "ENSINAR E APRENDER: SUJEITOS, SABERES, ESPAÇOS E TEMPOS”, 10., 2000, Rio de Janeiro. Anais... Rio de Janeiro, 2000. P. 67-68.

ALMEIDA, José Luís Vieira de. Interdisciplinaridade no Ensino: problema metodológico ou questão histórica?. In: ENCONTRO NACIONAL DE DIDÁTICA E PRÁTICA DE ENSINO, 11., 2002, Goiânia. Anais... Goiânia, 2002. P. 01-11.

ANHORN, Carmen Teresa Gabriel; MONTEIRO, Ana Maria Ferreira da Costa. Currículo, Ensino de História e Narrativa. In: REUNIÃO ANUAL DA ANPED, 30., 2007, Caxambu. Anais... Caxambu, 2007. P. 01-15.

ASSOCIAÇÃO NACIONAL DE PÓS-GRADUAÇÃO E PESQUISA EM EDUCAÇÃO (ANPED). Sobre a Anped. Rio de Janeiro, s.d. Disponível em: <http://www. anped.org.br/sobre-anped>. Acesso em 04 abr. 2018.

AZEVEDO, Heloisa Helena; TERCIOTTI, Adelei Hilda. Diretrizes Curriculares para a Formação de Professores e o Modelo Pedagógico de Competências. In: ENCONTRO NACIONAL DE DIDÁTICA E PRÁTICA DE ENSINO, 11., 2002, Goiânia. Anais... Goiânia, 2002. P. 01-06.

1716 Educação \& Realidade, Porto Alegre, v. 43, n. 4, p. 1693-1723, out./dez. 2018. 
BARBOSA, Derly et al. Interdisciplinaridade na Formação dos Professores. In: ENDIPE - "OLHANDO A QUALIDADE DO ENSINO A PARTIR DA SALA DE AULA", 9., 1998, Águas de Lindóia. Anais... Águas de Lindóia, 1998. P. 531-532.

BENÁCCHIO, Rosilda. Ensino de história na formação de professores para as séries iniciais e educação de jovens, adultos e idosos. In: ENDIPE - "DIDÁTICA E PRÁTICAS DE ENSINO: COMPROMISSO COM A ESCOLA PÚBLICA, LAICA, GRATUITA E DE QUALIDADE”, 26., 2012, Campinas. Anais... Campinas, 2012. P. 6736- 6747 .

BITTENCOURT, Jane. Interdisciplinaridade nas Séries Iniciais: considerações epistemológicas e didáticas a partir de uma disciplina. In: ENDIPE - "FORMAÇÃO E PROFISSIONALIZAÇÃO DO EDUCADOR”, 8., 1996, Florianópolis. Anais... Florianópolis: UFSC, 1996. P. 199-199.

BORGES, Lívia Freitas Fonseca. Eixo Estruturante e Transversalidade: elementos orientadores dos currículos da formação de profissionais da educação. In: CAVALCANTE, Maria Marina Dias; SALES, José Albio Morreira de; FARIAS, Isabel Maria Sabino de; LIMA, Maria do Socorro Laura (Org.). Didática e Prática de Ensino: diálogos sobre a escola, a formação de professores e a sociedade. 1. ed. Fortaleza: UECE; ENDIPE, 2014. P. 1181-1199.

BRASIL. Lei no 9.394, de 20 de dezembro de 1996. Estabelece as diretrizes e bases da educação nacional. Diário Oficial da União, Brasília, DF, 23 dez. 1996. P. 27833.

BRASIL. Parecer CNE/CP no 28, de 2 de outubro de 2001. Dá nova redação ao Parecer CNE/CP 21/2001, que estabelece a duração e a carga horária dos cursos de Formação de Professores da Educação Básica, em nível superior, curso de licenciatura, de graduação plena. Brasília, Diário Oficial da União, Brasília, DF, 18 jan. 2002. P. 31.

BRASIL. Ministério de Educação. Resolução CNE/CP 1/2006. Estabelece as diretrizes Curriculares Nacionais para o Curso de Graduação em Pedagogia, licenciatura. Diário Oficial da União, Brasília, 16 maio 2006. P. 11. Seção 1.

BRASIL. Ministério da Educação. Resolução n 2, de $1^{\circ}$ de julho de 2015. Define as Diretrizes Curriculares Nacionais para a formação inicial em nível superior (cursos de licenciatura, cursos de formação pedagógica para graduados e cursos de segunda licenciatura) e para a formação continuada. Diário Oficial da União, Brasília, DF, 2 jul. 2015. P. 8-12.

BRZEZINSKI, Iria. Memória, cultura, identidades e desafios do Curso de Pedagogia. In: ENCONTRO NACIONAL DE DIDÁTICA E PRÁTICA DE ENSINO “TRAJETÓRIAS E PROCESSOS DE ENSINAR E APRENDER: POLÍTICAS E TECNOLOGIAS”, 14., 2008, Porto Alegre. Anais... Porto Alegre: EdiPUC RS, 2008. P. 205-226

CAMARGO, Arlete Maria Monte. Políticas Curriculares para a Formação de Professores das Séries Iniciais do Ensino Fundamental. In: ENDIPE - "IGUALDADE E DIVERSIDADE NA EDUCAÇÃO”, 11., 2002, Goiânia. Anais... Goiânia, 2002. P. 220-241.

CARNEIRO, Antonio Lineu et al. O Conhecimento e a Interdisciplinaridade: primeiras reflexões. Educar em Revista, Curitiba, v. 10, n. 10, p. 33-38, jan./ dez. 1994.

CASTRO, César Augusto. Da interdisciplinaridade hipotética de um currículo a um currículo interdisciplinarmente materializado. In: REUNIÃO ANUAL DA ANPED, 30., 2007, Caxambu. Anais... Caxambu, 2007. P. 01-16.

Educação \& Realidade, Porto Alegre, v. 43, n. 4, p. 1693-1723, out./dez. 2018.1717 
Currículo e Ensino de História

CESCO, Susana; MOREIRA, Roberto José; LIMA, Eli de Fátima Napoleão de. Interdisciplinaridade, entre o conceito e a prática um estudo de caso. Revista Brasileira de Ciências Sociais, São Paulo, v. 29, n. 84, p. 57-71, 2014.

DAVID, Solange Ramos de Andrade. Por uma Teoria da Prática de Ensino de História. In: ENDIPE - "FORMAÇÃO E PROFISSIONALIZAÇÃO DO EDUCADOR", 8., 1996, Florianópolis. Anais... Florianópolis: UFSC, 1996. P. 220-221.

DIAS, Rosanne Evangelista. Competências: um conceito recontextualizado no currículo para formação de professores no Brasil. In: REUNIÃO ANUAL DA ANPED, 23., 2000, Caxambu. Anais... Caxambu, 2001. P. 01-15.

DOMINGUES, José Luiz. Didática e Currículo: continuando o diálogo. In: ENDIPE - "FORMAÇÃO E PROFISSIONALIZAÇÃO DO EDUCADOR", 8., 1996, Florianópolis. Anais... Florianópolis: UFSC, 1996. P. 458-459.

FAZENDA, Ivani Catarina Arantes. Integração e Interdisciplinaridade no Ensino Brasileiro: efetividade ou ideologia. São Paulo: Edições Loyola, 2002.

FAZENDA, Ivani Catarina Arantes. Interdisciplinaridade-Transdisciplinaridade: visões culturais e epistemológicas e as condições de produção. (Mesa-redonda). In: ENDIPE -“TRAJETÓRIAS E PROCESSOS DE ENSINAR E APRENDER: LUGARES, MEMÓRIAS E CULTURAS” 14., 2008, Porto Alegre. Anais... Porto Alegre: PUCRS, 2008. P. 20-28.

FAZENDA, Ivani Catarina Arantes. Interdisciplinaridade: história, teoria e pesquisa. Campinas: Papirus, 2012.

FELÍCIO, Helena Maria dos Santos. A integração Curricular na Educação em Tempo Integral: perspectivas de uma parceria interinstitucional. In: REUNIÃO ANUAL DA ANPED - "EDUCAÇÃO E JUSTIÇA SOCIAL”, 34., 2011, Natal. Anais... Natal, 2011. P. 1145-1156.

FERNANDES, José Ricardo Oriá. A Concepção de História no Ensino Fundamental: noções de tempo e sujeito histórico. In: ENDIPE - "PRODUÇÃO DO CONHECIMENTO E TRABALHO DOCENTE”, 7., 1994, Goiânia. Anais... Goiânia: UFG, 1994. P. 151-151.

FERREIRA, Eveline Andrade. Interdisciplinaridade e Formação de Pedagogos: aprendizagens da construção de uma experiência na educação superior em Sobral-Ceará. In: ENCONTRO NACIONAL DE DIDÁTICA E PRÁTICAS DE ENSINO - "DIDÁTICA E PRÁTICAS DE ENSINO: COMPROMISSO COM A ESCOLA PÚBLICA, LAICA, GRATUITA E DE QUALIDADE”, 16., 2012, Campinas. Anais... Campinas, 2012. P. 2-12.

FERREIRA, Norma Sandra de Almeida. As Pesquisas Denominadas "Estado da Arte”. Revista Educação \& Sociedade, Campinas, v. 23, n. 79, p. 257-272, ago. 2002.

FERREIRA, Priscila Ribeiro. O Processo de Elaboração Conceitual no Ensino de História e Geografia nas Séries Iniciais da Escolaridade. In: ENDIPE - "OLHANDO A QUALIDADE DO ENSINO A PARTIR DA SALA DE AULA”, 9., 1998, Águas de Lindóia. Anais... Águas de Lindóia: USP, 1998.

FIALHO, Lia Machado Fiúza; MACHADO, Charliton José dos Santos. Temas Transversais e Ensino de História nos Primeiros Anos de Escolarização. In: CAVALCANTE, Maria Marina Dias; SALES, José Albio Morreira de; FARIAS, Isabel Maria Sabino de; LIMA, Maria do Socorro Laura (Org.). Didática e Prática de Ensino: diálogos sobre a escola, a formação de professores e a sociedade. 1. ed. Fortaleza: UECE; ENDIPE, 2014. P. 4544-4554.

FIGUEIREDO, Jocinete das Graças. A Interdisciplinaridade e o Currículo Disciplinar: limites teórico-práticos dessa relação. In: ENDIPE - "CONHECIMENTO

1718 Educação \& Realidade, Porto Alegre, v. 43, n. 4, p. 1693-1723, out./dez. 2018. 
UNIVERSAL E CONHECIMENTO LOCAL”, 12., 2004, Curitiba. Anais... Curitiba: PUC Paraná, 2004. P. 275-289.

FREITAS, Luís Carlos de. Crítica da Organização do Trabalho Pedagógico e da Didática. Campinas: Papirus, 1995.

FREITAS, Luís Carlos de. Interações Possíveis entre a Área de Currículo e a Didática: o caso da avaliação. Revista Pro-Posições, Campinas, v. 9, n. 3, p. 28-42, nov. 1998

FRIGOTTO, Gaudêncio; JANTSCH, Ari Paulo. A Interdisciplinaridade como Necessidade e como Problema nas Ciências Sociais. In: JANTSCH, Ari Paulo; BIANCHETTI, Lucídio (Org.). Interdisciplinaridade: para além da filosofia do sujeito. Petrópolis: Vozes, 1995. P. 25-50.

GABRIEL, Carmen Teresa. O Saber Histórico Escolar: entre o universal e o particular (construindo diferenças e verdades através de história). In ENDIPE - "ENSINAR E APRENDER: SUJEITOS, SABERES, ESPAÇOS E TEMPOS”, 10., 2000, Rio de Janeiro. Anais... Rio de Janeiro, 2000. P. 425-437.

GALIAN, Cláudia Valentina Assumpção; LOUZANO, Paula Baptista Jorge. Michael Young e o Campo do Currículo: da ênfase no 'conhecimento dos poderosos' à defesa do 'conhecimento poderoso'. Revista Educação e Pesquisa, São Paulo, v. 40, n. 4, p. 1109-1124, out./dez. 2014.

GAMA, Carolina Nozella; JUNIOR, Cláudio de Lira Santos. Formação de Professores nas Teses sobre o Currículo de Pedagogia no Brasil. In: ENDIPE - "DIDÁTICA E PRÁTICAS DE ENSINO: COMPROMISSO COM A ESCOLA PÚBLICA, LAICA, GRATUITA E DE QUALIDADE”, 26., 2012, Campinas. Anais... Campinas, 2012. P. 6086-6097.

GASPARELLO, Arlette; NIKITIUK, Sônia Maria. Mudanças Históricas/Mudanças no Ensino de História. In: ENDIPE - "PRODUÇÃO DO CONHECIMENTO E TRABALHO DOCENTE”, 7., 1994, Goiânia. Anais... Goiânia: UFG, 1994. P. 152-152.

GATTÁS, Maria Lúcia Borges; FUREGATO, Antonia Regina Ferreira. Interdisciplinaridade: uma contextualização. Acta Paulista de Enfermagem, São Paulo, v. 19, n. 3, p. 323-327, 2006.

JANTSCH, Ari Paulo. O Conceito de Interdisciplinaridade e a Cultura Universitária. (Mesa-redonda). In: ENCONTRO NACIONAL DE DIDÁTICA E PRÁTICA DE ENSINO - "TRAJETÓRIAS E PROCESSOS DE ENSINAR E APRENDER: POLÍTICAS E TECNOLOGIAS”, 14., 2008, Porto Alegre. Anais... Porto Alegre: EdiPUC RS, 2008. P. 1-10.

JANTSCH, Ari Paulo; BIANCHETTI, Lucídio (Org.). Interdisciplinaridade: para além da filosofia do sujeito. Petrópolis: Vozes, 1995.

JAPIASSU, Hilton. Interdisciplinaridade e Patologia do Saber. Rio de Janeiro: Imago, 1976.

LACLAU, Ernesto. Hegemony and Socialist Strategy: towards a radical democratic politics. 2. ed. Londres: Verso, 2001.

LIBÂNEO, José Carlos. Os Campos Contemporâneos da Didática e do Currículo: aproximações e diferenças. In: OLIVEIRA, Maria Rita (Org.). Confluências e Divergências entre Didática e Currículo. Campinas, SP: Papirus, 1998. P. 53-92. LIBÂNEO, José Carlos. Diretrizes Curriculares da Pedagogia: imprecisões teóricas e concepção estreita da formação profissional de educadores. Educação \& Sociedade, Campinas, v. 27, n. 96, p. 843-876, 2006.

LIMA, André Pietsch. Construindo Interpretações sobre Integração Disciplinar: análises de uma experiência de inovação curricular a partir de produções

Educação \& Realidade, Porto Alegre, v. 43, n. 4, p. 1693-1723, out./dez. 2018.1719 
de alunos e professores. In: ANPED. Educação: manifestos, lutas e utopias. Petrópolis: Vozes, 2002. P. 164-165.

LUCK, Heloísa. Pedagogia Interdisciplinar: fundamentos teóricos e metodológicos. Rio de Janeiro: Editora Vozes, 1994.

LUZ, Everaldo de Souza. Ensino Profissional Integrado: projetos de trabalho sob a ótica da transdisciplinaridade. In: REUNIÃO ANUAL DA ANPED, 32., 2009, Caxambu. Anais... Caxambu: ANPEd, 2009. P. 01-16.

MALANCHEN, Julia. Cultura, Conhecimento e Currículo: contribuições da pedagogia histórico-crítica. Campinas: Autores Associados, 2016.

MANCINI, Ana Paula; MELLO, Lucrécia Stringhetta. Construindo o Currículo numa Visão Interdisciplinar. In: ENDIPE - "FORMAÇÃO E PROFISSIONALIZAÇÃO DO EDUCADOR”, 8., 1996, Florianópolis. Anais... Florianópolis: UFSC, 1996. P. 265-266.

MARIANO, Lidiane Aparecida Ferreria; MELLO, Lucrécia Stringhetta. A Produção do Conhecimento a partir da Pedagogia de Projetos: as múltiplas possibilidades da interdisciplinaridade em compasso com os temas transversais. In: ENDIPE “CONHECIMENTO LOCAL E CONHECIMENTO UNIVERSAL”, 12. 2004, Curitiba. Anais... Curitiba: PUC/PR, 2004. P. 1649-1655.

MARTINS, Katarina Maria. O Ensino da História e da Geografia: o método e o conteúdo. In: ENDIPE - "FORMAÇÃO E PROFISSIONALIZAÇÃO DO EDUCADOR”, 8., 1996, Florianópolis. Anais... Florianópolis: UFSC, 1996. P. 445-446.

MARTINS, Maria do Carmo. História, Currículos e Práticas Pedagógicas: sobre memórias e narrativas. In: REUNIÃO ANUAL DA ANPED - "EDUCAÇÃO, CULTURA E CONHECIMENTO NA CONTEMPORANEIDADE: DESAFIOS E COMPROMISSOS”, 29., 2006, Caxambu. Anais... Caxambu, 2006. P. 01-11.

MASCARENHAS, Ângela Cristina. Estudos Sociais no Ensino Fundamental na Rede Pública Municipal de Goiânia. In: ENDIPE - "PRODUÇÃO DO CONHECIMENTO E TRABALHO DOCENTE”, 7., 1994, Goiânia. Anais... Goiânia: UFG, 1994. P. 620-621.

MATHEUS, Danielle dos Santos. O Processo de Significação da Política de Integração Curricular em Niterói, RJ. In: REUNIÃO ANUAL DA ANPED, 32., 2009 Caxambu. Anais... Caxambu: ANPEd, 2009. P. 01-16.

MINAYO, Maria Cecília de Souza. Interdisciplinaridade: funcionalidade ou utopia?. Saúde \& Sociedade, São Paulo, v. 3, n. 2, p. 42-63, 1994.

MORAIS, Gelcivânia Mota Silva. Interdisciplinaridade: condição essencial para uma prática de ensino significativa. In: ENDIPE - "OLHANDO A QUALIDADE DO ENSINO A PARTIR DA SALA DE AULA”, 9., 1998, Águas de Lindóia. Anais... Águas de Lindóia, 1998. P. 451-452.

MORAIS, Grinaura Medeiros de. Ser Professor de História para Crianças. In: ENCONTRO NACIONAL DE DIDÁTICA E PRÁTICA DE ENSINO - "TRAJETÓRIAS E PROCESSOS DE ENSINAR E APRENDER: POLÍTICAS E TECNOLOGIAS”, 14., 2008, Porto Alegre. Anais... Porto Alegre: EdiPUC RS, 2008. P. 45-56.

MOREIRA, Antonio Flávio Barbosa. Multiculturalismo, Currículo e Formação de Professores. (Mesa-Redonda). In: ENDIPE - "OLHANDO A QUALIDADE DO ENSINO A PARTIR DA SALA DE AULA”, 9., 1998, Águas de Lindóia. Anais... Águas de Lindóia, 1998. P. 22-37.

MOREIRA, Antonio Flavio Barbosa. Propostas Curriculares Alternativas: limites e avanços. Educação \& Sociedade, Campinas, v. 21, n. 73, p. 109-138, dez. 2000.

1720 Educação \& Realidade, Porto Alegre, v. 43, n. 4, p. 1693-1723, out./dez. 2018. 
MOREIRA, Antonio Flavio Barbosa. Currículo, Cultura e Formação de Professores. Educar em Revista, Curitiba, v. 17, n. 17, p. 39-52, jan./jun. 2001.

MOREIRA, Antonio Flavio Barbosa. O Campo do Currículo no Brasil: construção no contexto da ANPED. Cadernos de Pesquisa, Rio de Janeiro, n. 117, p. 81101, nov. 2002.

MOREIRA, Antonio Flavio Barbosa. Estudos de Currículo: avanços e desafios no processo de internacionalização. Cadernos de Pesquisa, Rio de Janeiro, v. 39, n. 137, p. 367-381, maio/ago. 2009.

MOREIRA, Maria de Fátima Salum. O Ensino de História nas Séries Iniciais do $1^{\circ}$ Grau. In: ENDIPE - "PRODUÇÃO DO CONHECIMENTO E TRABALHO DOCENTE”, 7., 1994, Goiânia. Anais... Goiânia: UFG, 1994. P. 150-150.

MORIN, Edgar. Introdução ao Pensamento Complexo. Porto Alegre: Sulina, 2006.

MOURA, Dácio Guimarães; FERREIRA, Nali Rosa Silva. As Concepções de Transversalidade, Interdisciplinaridade e Transdisciplinaridade (TIT) como Base para a Nova Formação de Profissionais da Educação Básica. In: ENDIPE, 11., 2002, Goiânia. Anais... Goiânia, 2002. P. 01-10.

NADAI, Elza. O Ensino de História no $2^{\circ}$ Grau: problemas, deformações e perspectivas. In: ENCONTRO NACIONAL DE PRÁTICA DE ENSINO, 2., 1983, São Paulo. Anais... São Paulo: USP, 1983. P. 261-276.

OLIVEIRA, Ana de. A Disciplina Escolar História: reinterpretações curriculares no contexto da prática. In: REUNIÃO ANUAL DA ASSOCIAÇÃO NACIONAL DE PÓS-GRADUAÇÃO E PESQUISA EM EDUCAÇÃO, 28., 2005, Caxambu. Anais... Caxambu, 2005. P. 01-05.

OLIVEIRA, Ana. O campo pedagógico como antagonismo nas políticas curriculares para o ensino da História. In: REUNIÃO NACIONAL DA ANPED, 37, 2015, Florianópolis. Anais... Florianópolis, 2015. P. 01-14.

OLIVEIRA, Sandra Regina Ferreira de; ZAMBONI, Ernesta Zamboni; CAIMI, Heloísa. O Professor e a História Ensinada e Aprendida nos Anos Iniciais do Ensino Fundamental: trilhas a percorrer. In: ENDIPE - "CONVERGÊNCIAS E TENSÕES NO CAMPO DA FORMAÇÃO E DO TRABALHO DOCENTE: POLÍTICAS E PRÁTICAS EDUCACIONAIS”, 15., 2010. Belo Horizonte. Anais... Belo Horizonte: UFMG, 2010. P. 3214-3228.

OLIVEIRA, Zeli de; FONSECA, Selva. Saberes e Práticas Avaliativas no Ensino de História. In: ENDIPE - "CONHECIMENTO UNIVERSAL E CONHECIMENTO LOCAL”, 12., 2004, Curitiba. Anais... Curitiba: PUC Paraná, 2004. P. 1145-1158.

PACKER, Abel; COP, Nicholas; SANTOS, Solange. A Rede SciELO em Perspectiva. In: PACKER, Abel (Org.). PACKER, Abel et al. SciELO - 15 Anos de Acesso Aberto: um estudo analítico sobre acesso aberto e comunicação científica. Paris: UNESCO, 2014. P. 41-66.

PEREIRA, Maria Lúcia Toralles; FORESTI, Miriam Celí Pimentel. Formação Profissional: reflexões sobre interdisciplinaridade. Interface - Comunicação, Saúde, Educação, Botucatu, v. 2, n. 3, p. 149-152, ago. 1998.

PESSOA, Valda Inês Fontenele. O Cuidado Interdisciplinar em um Currículo de Formação Docente. In: ENDIPE - "DIDÁTICA E PRÁTICAS DE ENSINO: COMPROMISSO COM A ESCOLA PÚBLICA, LAICA, GRATUITA E DE QUALIDADE”, 26., 2012, Campinas. Anais... Campinas, 2012. P. 2684-2695.

PINTO, Marly Maria Santos. Interdisciplinaridade: uma proposta de ensino através de temas geradores. In: ENDIPE - "FORMAÇ̃̃O E PROFISSIONALIZA-

Educação \& Realidade, Porto Alegre, v. 43, n. 4, p. 1693-1723, out./dez. 2018.1721 
Currículo e Ensino de História

ÇÃO DO EDUCADOR”, 8., 1996, Florianópolis. Anais... Florianópolis: UFSC, 1996. P. 265-265.

PIRES, Marília Freitas de Campos. Multidisciplinaridade, Interdisciplinaridade e Transdisciplinaridade no Ensino. Interface - Comunicação, Saúde, Educação, São Paulo, v. 2, n. 2, p. 173-182, 1998.

PUGAS, Márcia Cristina de Souza; RAMOS, Ana Paula Batalha. Articulações Discursivas sobre Conhecimento no Currículo de Pedagogia. In: REUNIÃO ANUAL DA ANPED, 35., 2012, Ipojuca. Anais... Ipojuca, 2012. P. 01-15.

RIBEIRO, Álvaro Sebastião Teixeira. Transversalidade na Educação: uma possibilidade significativa para tornar a educação mais dinâmica e oportuna. In: ENCONTRO NACIONAL DE DIDÁTICA E PRÁTICA DE ENSINO, 11., 2002, Goiânia. Anais... Goiânia, 2002. P. 272-285.

RIBEIRO, Márcia Maria Gurgel. Currículo de Formação de Professores para Séries Iniciais do Ensino Fundamental: uma reflexão sócio-histórica. In: ENDIPE, 13., 2006, Recife. Anais... Recife, 2006. P. 01-11.

ROMANO, Regina Aurora Trino. Currículo Integrado: uma construção de sujeitos, um processo e uma práxis. In: ENDIPE - "ENSINAR E APRENDER: SUJEITOS, SABERES, ESPAÇOS E TEMPOS”, 10., 2000, Rio de Janeiro. Anais... Rio de Janeiro, 2000. P. 107-108.

SÁ, Eliana Maria de Oliveira; VILELA, Rita Amélia Teixeira. Quando o Currículo faz a Diferença... o currículo integrado na formação em serviço do técnico em higiene dental (THD). In: REUNIÃO ANUAL DA ASSOCIAÇÃO NACIONAL DE PÓS-GRADUAÇ̃̃O E PESQUISA EM EDUCAÇ̃̃O, 24., 2001, Caxambu. Anais... Caxambu, 2001. P. 01-19.

SACRISTÁN, Jose. O Currículo: uma reflexão sobre a prática. 3. ed. Porto Alegre: Artes Médicas, 2000.

SANTOMÉ, Jurjo Torres. Globalização e Interdisciplinaridade: o currículo integrado. Porto Alegre: Artes Médicas, 1998.

SANTOS, Joana Ribeiro dos. Tessitura de uma alternativa curricular a partir das vivências cotidianas: o ensino de História e a sala de aula como espaçotempo de pesquisa. In: REUNIÃO NACIONAL DA ANPED, 37., 2015, Florianópolis. Anais... Florianópolis, 2015. P. 01-18.

SANTOS, Leila Camelo dos; LOPES, Alice Casimiro. A Produção Brasileira sobre Integração Curricular (Anos 80 e 90). In: ENCONTRO NACIONAL DE DIDÁTICA E PRÁTICA DE ENSINO, 11., 2002, Goiânia. Anais... Goiânia, 2002. P. 20-32.

SAVIANI, Dermeval. A Questão Pedagógica na Formação de Professores. Florianópolis: Endipe, 1996.

SAVIANI, Dermeval. O Espaço Acadêmico da Pedagogia no Brasil: perspectiva histórica. Paidéia, Ribeirão Preto, v. 14, n. 28, p. 113-124, 2004.

SAVIANI, Dermeval. Pedagogia: o espaço da educação na universidade. Cadernos de Pesquisa, Rio de Janeiro, v. 37, n. 130, p. 99-134, 2007.

SAVIANI, Dermeval. Formação de Professores: aspectos históricos e teóricos do problema no contexto brasileiro. Revista Brasileira de Educação, Campinas, v. 14, n. 40, p. 143-155, jan./abr. 2009.

SCHEIBE, Leda. A Formação do Pedagogo: um desafio para o século XXI. (Mesa-redonda). In: ENCONTRO NACIONAL DE DIDÁTICA E PRÁTICA DE ENSINO - "TRAJETÓRIAS E PROCESSOS DE ENSINAR E APRENDER: POLÍTICAS E TECNOLOGIAS”, 14., 2008, Porto Alegre. Anais... Porto Alegre: EdiPUC RS, 2008. P. 297-310.

1722 Educação \& Realidade, Porto Alegre, v. 43, n. 4, p. 1693-1723, out./dez. 2018. 
SEREJO, Hilton Fabiano Boaventura. A Educação Superior e suas Relações com a Teoria Curricular. In: ENCONTRO NACIONAL DE DIDÁTICA E PRÁTICA DE ENSINO, 11., 2002, Goiânia. Anais... Goiânia, 2002. P. 240-241.

SILVA, Marcos Antônio da; FONSECA, Selva Guimarães. Ensino de História hoje: errâncias, conquistas e perdas. Revista Brasileira de História, São Paulo, v. 31, n. 60, p. 13-33, 2010.

SILVA, Vânia Beatriz Monteiro da. Currículo Emergente e Aprendizagens Docentes no Curso de Pedagogia. In: ENDIPE - "ENSINAR E APRENDER: SUJEITOS, SABERES, ESPAÇOS E TEMPOS”, 10., 2000, Rio de Janeiro. Anais... Rio de Janeiro, 2000. P. 262-263.

SOARES, Olavo Pereira. Pesquisas e Propostas Curriculares para o Ensino de História: a diversidade como hegemonia. In: REUNIÃO ANUAL DA ANPED, 34., 2011, Natal. Anais... Natal, 2011. P. 01-10.

SOSSAI, Fernando César; LUNARDI, Geovana Mendonça. Currículo e Ensino de História: desencaixes e reencaixes em um mundo de globalizações. In: REUNIÃO ANUAL DA ANPED, 32., 2009, Caxambu. Anais... Caxambu: ANPEd, 2009. P. 01-18.

SOUZA, Patrícia Alves de; ZEFERINO, Angelica Maria Bicudo; DA ROS, Marco Aurélio. Currículo Integrado: entre o discurso e a prática. Revista Brasileira de Educação Médica, Brasília, v. 35, n. 1, p. 20-25, 2011.

TEÓFILO, Vanilda Maria Santos. Formação de professores: uma perspectiva interdisciplinar. In: ENDIPE, 13., 2006, Recife. Anais... Recife, 2006. P. 01-13.

VEIGA-NETO, Alfredo. Cooperação Interdisciplinar e Produção do Conhecimento em Educação: ressignificações semânticas no campo das disciplinas. (Sessão Especial). In: REUNIÃO ANUAL DA ANPED, 30., 2007, Caxambu. Anais... Caxambu, 2007. P.01-02.

VELHO, Otávio. Os Novos Sentidos da Interdisciplinaridade. Mana, Rio de Janeiro, v. 16, n. 1, p. 213-226, 2010.

YOUNG, Michael. Para que Servem as Escolas? Revista Educação \& Sociedade, Campinas, v. 28, n. 101, p. 1287-1302, set./dez. 2007.

YOUNG, Michael. The Curriculum and the Entitlement to Knowledge. In: SEMINAR ORGANISED BY CAMBRIDGE ASSESSMENT NETWORK, 2014, Cambridge. Anals... Cambridge: Magdalene College, 2014. P. 1-10.

ZAMBONI, Ernesta. Representações e Linguagens no Ensino de História. Revista Brasileira de História, São Paulo, v. 18, n. 36, p. 89-102, 1998.

Francisco Thiago Silva é doutor e Mestre em Educação e Currículo pela UnB. Licenciado em História e Pedagogia. Professor da Secretaria de Educação do Distrito Federal e do Centro Universitário Projeção, DF. E-mail: fthiago2002@yahoo.com.br

Lívia Freitas Fonseca Borges é doutora em Sociologia (UnB) e Mestre em Educação (UnB). Professora associada da Faculdade de Educação, UnB. Atual diretora da FE.

E-mail: liviaffb@terra.com.br

Este é um artigo de acesso aberto distribuído sob os termos de uma Licença Creative Commons Atribuição 4.0 Internacional. Disponível em: $<$ http://creativecommons.org/licenses/by/4.0>.

Educação \& Realidade, Porto Alegre, v. 43, n. 4, p. 1693-1723, out./dez. 2018.1723 